\title{
Cyberpunk Türü ve Örnek Filmlerin İç Mekân Analizi
}

\author{
İç Mimar Süphan Kaan Çiftci ${ }^{*}$ \\ Doç. Dr. Deniz Demirarslan ${ }^{2}$
}

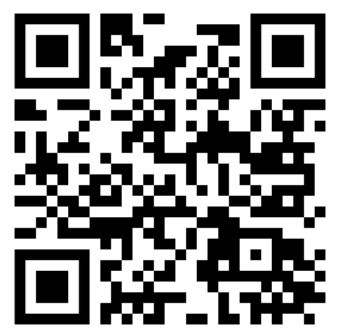

Geliș tarihi: 12.06 .2020

Kabul tarihi: 07.09.2020

\section{Atıf bilgisi:}

IBAD Sosyal Bilimler Dergisi

Sayı: Özel Sayı Sayfa: $62-83$

Yıl: 2020

This article was checked by Turnitin. Similarity Index 13\%

Bu makalede araştırma ve yayın etiğine uyulmuştur.

\section{${ }^{1}$ Kocaeli Üniversitesi, Türkiye, suphanciftci@gmail.com, ORCID ID 0000-0001-5875-142X}

2Kocaeli Üniversitesi, Türkiye, demirarslandeniz@gmail.com, ORCID ID 0000-0002-7817-5893

* Sorumlu yazar
$\ddot{O} \mathbf{z}$

Cyberpunk teknolojinin hat safhaya ulaștığı, yapay zekanın insan zekasına eş değer konuma geldiği, makine-insan birleşimlerinin yaşandığı, transhümanizmin benimsendiği, karanlık ve kaos içeren bir geleceğin tasvir edildiği bir bilim kurgu dalı olarak tanımlanmaktadır. Teknolojinin sürekli olarak devinim ve gelişim halinde olması gelecek yıllarda hayatımızın her alanında teknolojiyle iç içe olmayı gerektirecektir. 1980'lerden bu yana edebiyat başta olmak üzere, müzik, video oyunları ve sinema sektöründe Cyberpunk türünde birçok eser verilmiştir. Özellikle sinema sektörü bu türü kısa sürede benimsemiş ve yıllar içinde değişim göstererek çok sayıda eser sunmuştur. Sinema sektörü Cyberpunk'1 görsel bağlamda bizlere en iyi şekilde aktarmaktadır. Bu araștırmada elli adet Cyberpunk türünde film örnek olarak verilmiş ve aralarından üç adet film, içerdiği iç mekân verileri açısından incelenmek için tercih edilmiştir. Filmler birden çok kez izlenmiş ve görsel göstergebilim metoduyla incelenmiştir. Kesin yargıları olmayan, hala gelişmekte ve değişmekte olan Cyberpunk türü ile üretilen filmlerin iç mekân tasarımı açısından benzer özelliklerine değinilmiştir. İncelenen bu üç filmde, iç mekân tasarımı ve mobilya tasarımına dair detaylı bir çalışmanın mevcut olmadığı görülmüştür. Filmlerde ortak olarak iç mekânlar soğuk ve kasvetli olarak tasvir edilmis, mobilyalar genelde modern ve fütüristik çizgide kullanılmıştır. Gelecek yüzyılda teknolojinin bu denli gelişmesiyle sadece insan-makine birleșimi değil; aynı zamanda mobilya ve iç mekânın teknoloji ile birleşimi de göz önüne alınmalıdır. Bu sayede gelişmiş teknolojiyi insan hayatının yararına, yaşam kalitesini yükseltmek amaciyla kullanmak mümkündür.

Anahtar Kelimeler: Cyberpunk, Sinema, İç mekân, Mobilya, Teknoloji 


\title{
Cyberpunk Genre and Interior Space Analyses of Cyberpunk Movies
}

\author{
Interior Architect Süphan Kaan Çiftci ${ }^{1^{*}}$ \\ Assoc. Prof. Dr. Deniz Demirarslan ${ }^{2}$
}

First received: 12.06 .2020 Accepted: 07.09.2020

\section{Citation:}

IBAD Journal of Social Sciences

Issue: Special Issue

Year: 2020

This article was checked by Turnitin. Similarity Index $13 \%$

${ }^{1}$ Kocaeli University, Turkey, suphanciftci@gmail.com ORCID ID 0000-0001-5875-142X

2Kocaeli University, Turkey, demirarslandeniz@gmail.com, ORCID ID 0000-0002-7817-5893

* Corresponding Author

\begin{abstract}
Cyberpunk is defined as a science fiction genre where technology is at advanced stage, artificial intelligence is regarded at the same level with human intelligence, machine-human combinations are seen, transhumanism is adopted and a future including darkness and chaos is depicted. That the technology is in constant motion and improvement will require us to be hand in hand with technology in every corner of our lives in the years to come. Since 1980's, we have seen lots of works in Cyberpunk genre mainly in literature and also in music, video games and cinema sectors. Especially cinema sector adopted this genre very quickly and brought a great number of works by transforming throughout years. Cinema sector reflects Cyberpunk at the level in visual sense. In this study, fifty movies in Cyberpunk genre were given as sample and amongst them three of these movies were picked up for analysis in the sense of interior data. Movies were watched more than once and analyzed by visual semiotics method. Similar characteristics of interior designs in Cyberpunk movies which do not have final judgments and still being developed and transformed were analysed. In these three movies which have been analysed, it was observed that there is no detailed study carried out for interior design or furniture design. Commonly, interiors were depicted as cold and gloomy in the movies, modern and futuristic lines were used in the furniture. With the great improvement of technology in the future, not only human-machine combination but also the combination of furniture with interior technology should be taken into consideration. In this way it is possible to use advanced technology for the benefit of human life and in order to raise the quality of life.
\end{abstract}

Keywords: Cyberpunk, Cinema, Interior, Furniture, Technology 


\section{GíRIŞ}

Her yapı, toplumun ve bireylerin belirli ihtiyaçlarına cevap vermek amacıyla, dönemin inşaat tekniğine ve teknolojisine bağlı olarak bazı malzemelerle belirli fiziki mekânın çevresinin çevrilmesi ile oluşmuştur. İnsanın fiziksel mekâna yönelip orada belirli bir kısmı sınırlandırması, belirginleştirmesiyle mimari mekân oluşmuş olur. Başka bir deyişle mimari mekân özellikle izlenir, hissedilir bir duruma gelir (Altan, 1993, s.78).

Mimar Steen Rasmussen'e (2010) göre; insanların ihtiyaçları doğrultusunda oluşturulan biçimler olan mekânsal organizasyonlar, yalnızca dışarıdan bakılmak için değil; aynı zamanda içinde yaşamak için de oluşturulmuştur. Mimari mekânsal yapılar tüm duygular ve duyular yolu ile algılanır ve deneyimlenirler. Tüm duygulara hitap eden mekân, dokunsal, işitsel, kokusal özelliklerinin yanı sıra 1şıksal özellikleri ile de algilanirlar (akt. Usta, 2020, s.26).

Teknolojik gelişmeler, mekânların oluşumunu, işlevsel, boyutsal ve biçimsel olarak yenilenmesi ihtiyacını ortaya koymaktadır. İnsanların temel gereksinimlerini karşılayan hareketli veya hareketsiz donatıların boyutlarında çok fazla değişimler meydana gelmese de mekânın içerdiği ve mekân ile ilişkili olan teknolojik ekipmanlarda büyük değişimler yaşanmaktadır. Genel olarak mekân konforuna yönelik üretilen ürünler, ekipmanlar, donatılar, dönemin yaşam biçimlerine uygun ya da ihtiyaçları karş1layabilecek şekilde üretilmektedir (Özturan, 2010, s.127).

İç mekân tasarımı her zaman sinemanın önemli bir konusu olmuştur. Sinema türlerinde olan mekân yaratma kaygısı, filmlerin anlaşılabilir olması ve anlatılmak istenen duygunun seyirciye geçmesi açısından önemli bir konudur. Sinema görsel açıdan kurgulanmış tüm varsayımları somut bir şekilde insanlara sunma imkanına sahiptir. Çok sayıda insana ulaşabilen sinema bu noktada çok önemli bir araç durumundadır (Bezci ve Türkkan, 2017, s. 352). Sinema filmlerinde, yaşamdan kesitler, kısıtlı zaman ve mekânlar içinde sıkıştırılıp izleyicilere sunulmaktadır. Böylelikle fiziksel mekân sosyal girdiler ışığında kolayca anlaşı1ır hale gelmektedir. Bu bakımdan da tasarımcılar için sinema filmleri, kentin kendisi kadar mimarlık ve mekân oluşumunda model rol üstlenmektedir (Kutucu, 2003, s.26). Sinema, gerçekte var olmayan mimarinin kullanıldığı bir ortam olmakla beraber, mevcut mimari ile ilgili de izleyicilerde deneyimsel bir algı bırakabilen metotlara sahip bir sanat dalı olarak düşünülmektedir. Sinematografinin keşfinden günümüze, mimari mekân kavramları çeşitli üsluplar ile sinematik bir anlatım aracı olarak görülmektedir. Sinema dilini oluşturan diğer ögeler ile de doğrudan veya dolaylı olarak etkileşim halinde olan mekân, filmlerde görsel yapının merkezi, temel unsuru olarak yer almaktadır. Sinema mekânın fiziksel ögelerinin, mekânın ideolojisi ile bütünleşip algısal anlamda istenilen mesajın verilmesi ve yorumlanması ile mekâna kimlik katmaktadır. Mekân, sinema ve mimarlık arasında var olan ilişki arasında en etkili kavram olarak yer almaktadır. Bu ilişki, sinemanın mimarlık ile olan en somut, en sıkı bağı olarak yorumlanmaktadır (Ersoy, 2010, s.14-15). Sinema daha önce gidilmeyen yerleri deneyimleme firsatı sunmakta, bu yönüyle mimari kültüre ve eğitime katkı sağlamakta ve mekânsal tecrübe zenginliği yaratmaktadır. Sinema imgeleri insanların sosyal hayatını etkilemektedir. Filmlerle tanımlanmış zaman ve mekân kavramlarının insan zihnindeki görsel hafıza tarafından tecrübelenmesi ile gerçekleşmektedir (Beşışık, 2013, s.13).

1980'lerden bu yana değişim ve gelişim gösteren Cyberpunk türü olası gelecek senaryoları üzerinde örnekler vermektedir. Bu yapıtlarda çoğunlukla gelecekteki sorunlar ele alınmaktadır. Ülkelerin yönetim şekilleri, insanların çalışma sistemleri, yeni iş alanları, kaos ve karmaşanın hâkim olduğu bu senaryolarda teknolojinin geldiği nokta gösterilmektedir. İnsan-makine birleşimleri (cyborg), yapay zekâ, robotlaşma, hastalıklara ve zayıflıklara karşı direnç, transhümanizm gibi kavramlar göze çarpmaktadır. Böylesine bir gelecekte göz ardı edilmemesi gereken konulardan biri de iç mekân tasarımı ve mobilya tasarımıdır. Teknolojinin direkt olarak mekânlarla ve mobilyalarla iç içe olması önlenemez bir gerçektir.

$\mathrm{Bu}$ çalışmada bilimsel araştırma yöntemlerinden niteliksel yöntem grubuna dahil olan bağıntısal araştırma modeli ve gömülü teori modeli üzerinde durularak araştırmalar gerçekleştirilmiştir. 50 adet Cyberpunk temalı film örnek olarak gösterilmiş ve aralarından 3 adet film, incelenebilmesi açısından içerdiği iç mekân ve mobilya verileri, günümüz teknolojisine benzerlikleri ve gerçekleşme ihtimali daha yüksek teknolojileri barındırmalarından dolayı tercih edilmiştir. Bu filmler birden çok defa izlenerek, 
görsel göstergebilim metodu ile incelenmiş, iç mekân ve mobilyalar üzerinden analizler yapılmıştır. Bu filmlerin incelenip birbirleriyle ve mevcut yaşam mekânlarıyla karşılaştırılmasının yapılması ve elde edilen bulgular doğrultusunda bu mekân özelliklerinin kullanımı ile gerçek mekân tasarımlarının yapılabilmesi hedeflenmiştir.

\section{Cyberpunk Kavramı}

Cyberpunk sözcügü ilk olarak 1983 yılında 'Amazing Science Fictions Stories'” adlı dergide yayınlanan ve Bruce Bethke tarafından yazılan "Cyberpunk" adlı kısa öyküde kullanılmıştır. Cybernetics ve punk sözcüklerinin birleşimi ile ortaya çıkmış bir sözcüktür (Ersümer, 2013, s.17). Cyberpunk teknolojinin hat safhaya ulaştı̆̆ı, yapay zekanın insan zekasına eş değer konuma geldiği, makine-insan birleşimlerinin yaşandığı, transhümanizmin benimsendiği, karanlık ve kaos içeren bir geleceğin tasvir edildiği bir bilim kurgu dalı olarak tanımlanmaktadır. Bilim kurgu henüz gerçekleşmiş veya gerçekleşmemiş bütün zaman dilimleri ile ilgili öngörü ve varsayımlara dayalı, teknolojik gelişmeler doğrultusunda kurguyla oluşturulan yazım ve sinema türüdür (Bağcıvan ve Durmuş, 2019, s. 303). Cyberpunk ise, bazı yazar, senarist, yönetmen ve sinemacılara göre bilim kurgunun alt dalı olarak görülürken, bazılarına göre ise bilim kurgu kadar geniş ve kapsamlı bir türdür. Cyberpunk sözcüğünü oluşturan cybernetics, bir sistem olarak canlılarda ve makinelerde, iç ve dış bilgi alışverişini kontrol, denetim ve yönetim bilimine verilen addır (Ersümer, 2013, s.17). Punk ise 1970'lerde ekonomik krizin görüldüğü İngiltere'de ortaya çıkmıştır. Punk kişiler toplumun geleneksel tabularına karşı çıkmış, alışılagelmiş ahlaki değerleri kabul etmemiş gençlerdi. Bu hareketi savunanların gelecekten umutları yoktu ve 'Gelecek Yok" (No Future) sloganına sahiplerdi. Punk'ın barındırdığı temel unsurlar nihilizm, yabancılaşma, yok olma arzusu, teslimiyet, isyan, grotesk olana merak duyma, müstehcenlik, uyuşturucular ve argo olarak sıralanmaktadır. Punk görsel olarak itici ve tuhaf olmayı içermektedir. Punkların bir diğer sloganı olan "'Kendi İşini Kendin Yap" (Do-It-Yourself) tavrı ise Cyberpunk türündeki bilgisayar korsanlarının tavırları ile benzerlikler göstermektedir (Ersümer, 2013, s. 41-42).

Cyberpunk sözcüğündeki “cyber”' bileşeni, uzaygemileri ve robotlardan daha çok sibernetik üzerine vurgu yapmaktadır. "Punk" bileşeni ise sokak ve kent kültüründeki cüretkâr tavıra atıflarda bulunmaktadır. Cyberpunkta karakterler toplumun sınırında konumlanmış kişilerdir ve, uyumsuzlar, dışlanmışlar, psikopatlar olarak kabul görürler. Cyberpunk, ilk olarak William Gibson'ın Neuromancer romanında yer almış bir kavram olan siberuzay düşüncesinin kapsamlı bir biçimde uygulandığı bir gelecek önermesi sunmaktadır (Cavallaro, 2000, s.14).

Cyberpunk, 1970'li y1llarda sanayi sonrası modernleşmiş toplumlarda yaşanmış temel değişiklikleri yansıtır niteliktedir. Dönemin sosyal, kültürel, ekonomik, politik ve özellikle teknolojik gelişmeleri ile beslenir ve yakın zamanlı gelecek için öngörülerde bulunur (Ayyıldız ve Müştak, 2016, s. 130-131). Fakat Cyberpunk türü teknolojiyi kararlı bir düzeyde kullanarak ilerlese de tam olarak bekleneni verememiştir. 80'li yıllar bu türün ön plana çıktığı bir dönemdi ve bu dönemde dünyaca ünlenecek birçok yazılı eser ve filmler üretilmiştir. Yeni ve çağdaş olan bu tarz zamanla birlikte çokça değişim ve gelişim göstermiştir. Neredeyse tüm Cyberpunk türünde eserlerde çöküş ve istila insanlar tarafindan değil; dışarıdan gerçekleşmektedir. İnsanoğlundan daha üstün bir varlık yaratma arzusunda olan ülkeler ve çok uluslu kapitalizm bunlara sebep olmaktadır. Amerikalı bilim kurgu yazarı Bruce Sterling'e göre, Cyberpunk türünde eserlerde bedenlerin saldırıya uğraması ve zihnin saldırıya uğraması istila olarak görülmektedir. Bedenin istila teması: protez organlar, kozmetik cerrahi, vücuda yerleştirilen devreler ve genetik değişimler olarak yer bulurken, zihnin istilası: yapay zekâ, nörokimya ve beyin bilgisayar ara yüzleri olarak karşımıza çıkmaktadır (Ersümer, 2013, s. 53; Ayyıldız ve Müş̧ak, 2016, s. 131). William Gibson'ın kaleme aldığı Neuromancer (1984) ve 1982 yılında Ridley Scout'ın yönetmenliğini yaptığı Blade Runner filmi bu türün başyapıtları olarak gösterilmektedir. Bulunduğu dönemin teknolojik gelişmeleri doğrultusunda 1980'lerden günümüze birçok film yapılmış ve bu filmler teknolojik ve görsel açıdan gelişim göstermiş̧ir.

\section{Bilim Kurgu, Cyberpunk ve Sinema}

Bilim kurgu; gelecek ile ilgili olayları, güncel koşullarda ulaşılamayan teknolojiyi, sanat ve bilim ile harmanlayarak tasvir edilen gelecek öngörüleri olarak tanımlanabilmektedir. Bilim kurgu türünün yaratıcısı olarak görülen Hugo Gernsback'e göre bilim kurgu kavramı, 'bilimsel olgular ve kehanetlerle 
karşılaşmış, düşsel, sürükleyici bir öykünün tanımını yapmaktadır.' (Sevin, 2018, s.13). Geleceğe dayalı varsayımlar ile bilim kurgu filmleri, izleyiciye zaman içerisindeki deneyimlerinin ötesinde farklı fikirler sunarken, teknoloji ve bilim alanındaki gelişmelere de 1şık tutmaktadır. Bilim kurgu genelde günümüz koşullarını referans alarak geleceğe dair sağlam temelleri olan varsayımlarda bulunarak, gelecek dünya düzenleri ile ilgili zemin hazırlar. Robotlar, androidler, yapay zekâ, uzay, cyborglar bilim kurgunun barındırdığı temel unsurlardandır. Eserlerde zaman zaman robotların bağımsızlığı ile insanlığın sonu, hastalıklara çözüm, insanların makineleşmesi gibi transhümanist düşünceler, uzay yolculukları gibi konular ele alınmaktadır. Bilim kurgu, bireylerin birbirleriyle, teknolojiyle, toplumla ve çevreyle etkileşimleri üzerinde düşüncelere sebep olmamızı sağlar. Günümüz ve gelecek ile bir bağlantı kurarken, yapılan seçimlerin ve etkileşimlerin geleceği üretmeye, yol çizmeye katkıda bulunan farklı yolları düşünmeye teşvik eder (Bezci ve Dündar Türkkan, s. 354). Bilim kurgu eserlerinde yer alan nesneler ve tüm tasarımlar konsept tasarım olarak tanımlanır. Bu tasarımlar zihinde kavranan ve zihinde tasarlanan genel tasarımlardır. Sinemada bu tasarımların işlevinin simülasyonları izlenmektedir. Görsel sanatlara göre sinemada, bu tasarımların işlevi konusunda daha fazla fikir sahibi olunmaktadır. İşlevi yerine getirilemediği için bu tasarımlar, konsept tasarım olarak kalmaya devam eder (Bağcıvan ve Durmuş, 2019, s. 310).

Cyberpunk ise kimi yazar, yönetmen ve eleştirmenlere göre bilim kurgunun alt dalı olarak görülürken, bazı kesimlere göre bilim kurgu kadar geniş ve kapsamlı bir türdür. Cyberpunk türünün erken dönem bilimkurgu geleneklerinden en önemli farkı olarak, teknolojinin naif bir şekilde mitleştirilmesine karşın distopik bir şekilde gelişen teknolojinin gelecek varsayımlarında kararsız bir hale bürüneceği, bunun da toplum ve birey üzerinde çok ciddi sonuçlara yol açacağ yaklaşımıdır (Bağcıvan ve Durmuş, 2019, s. 312). Transhümanizm, insanın mevcut özelliklerinin ve potansiyellerinin güncel bilimsel ve teknolojik imkanlar aracıllğıyla değiştirilip geliştirilmesi ve tüm insanların buna erişebilir duruma getirilmesi olarak açıklanmaktadır (Uğur, 2018, s. 59-60). Cyberpunk türünde zaman, yüksek teknolojiye sahip makinelerle birlikte hareket etme zamanı olduğundan, savaş yine makineler aracılığı ile veya onlarla bütünleşerek yapılmaktadır. Eserlerde yer alan kahramanlar sokak tarzı ve sert konuşan genç kahramanlardır. Vücutlarına çeşitli makineler, implantlar ve protezler monte edilmiştir veya olağandışı iletişim yeteneklerine sahiptirler (Ersümer, 2013, s. 28; Sevin, 2018, s. 39). Cyberpunk varlıkları olağandan farklı ve yanlış bir düzen içinde yaşamaya mahkûm eder ve insanları makineye, makine ve androidleri ise insana dönüştürme kaygısı taşır. İnsan yaşamının robotlaşması ve dijitalleşmesi ile androidler, cyborglar gibi makinelerin insanlaşması üzerinde durur (Başaran, 2007, s. 25). Bazı eserlerde insanlar gibi düşünen, insanlardan daha insan olabilen androidler yer alırken, bazı eserlerde insanların makineleşmesi söz konusudur. Kapitalizm ve teknoloji devi şirketlerin, insandan daha güçlü bir form arzulaması sonucunda androidler ve transhümanizm gelişmektedir. Tablol'de Cyberpunk türünde filmlerin kronolojik olarak sıralaması yer almaktadır.

Tablo 1. Cyberpunk Türünde Filmler

\begin{tabular}{|c|c|c|}
\hline TARİH & FÍLM & YÖNETMEN \\
\hline \multirow{2}{*}{1982} & Blade Runner & Ridley Scott \\
\hline & Burst City & Gakuryū Ishii \\
\hline 1984 & Terminator & James Cameron \\
\hline \multirow[b]{2}{*}{1987} & Robocop & Paul Verhoeven \\
\hline & Meikyû Monogatari & $\begin{array}{c}\text { Katsuhiro Otomo, Yoshiaki } \\
\text { Kawajiri, Rintaro }\end{array}$ \\
\hline 1988 & Akira & Katsuhiro Otomo \\
\hline 1989 & Tetsuo & Shinya Tsukamoto \\
\hline \multirow{6}{*}{1990} & Total Recall & Paul Verhoeven \\
\hline & Megaville & Peter Lehner \\
\hline & Hardware & Richard Stanley \\
\hline & Circuitry Man & Steven \& Robert Lovy \\
\hline & Cyber City Oedo 808 & Yoshiaki Kawajiri \\
\hline & Robocop 2 & Irvin Kershner \\
\hline 1991 & Terminator 2: Judgment Day & James Cameron \\
\hline 1992 & The Lawnowner Man & Brett Leonard \\
\hline
\end{tabular}




\begin{tabular}{|c|c|c|}
\hline & Nemesis & Albert Pyun \\
\hline 1993 & Robocop 3 & Fred Dekker \\
\hline \multirow{3}{*}{1995} & Judge Dredd & Danny Cannon \\
\hline & Johnny Mnemonic & Robert Longo \\
\hline & Strange Days & Kathryn Bigelow \\
\hline 1997 & Nirvana & Gabriele Salvatores \\
\hline 1998 & New Rose Hotel & Abel Ferrara \\
\hline \multirow[b]{2}{*}{1999} & Matrix & Lana \& Lilly Wachowski \\
\hline & Existenz & David Cronenberg \\
\hline 2001 & Avalon & Mamoru Oshii \\
\hline 2002 & Minority Report & Steven Spielberg \\
\hline \multirow{4}{*}{2003} & Terminator 3: Rise of the Machines & Jonathan Mostow \\
\hline & Animatrix & $\begin{array}{c}\text { Shinichirō Watanabe, Takeshi } \\
\text { Koike, Koji Morimoto, Yoshiaki } \\
\text { Kawajiri, Peter Chung, Mahiro } \\
\text { Maeda, Andrew R. Jones }\end{array}$ \\
\hline & Matrix: Reloaded & Lana \& Lilly Wachowski \\
\hline & Matrix: Revolution & Lana \& Lilly Wachowski \\
\hline 2007 & The Gene Generation & Pearry Reginald Teo \\
\hline 2008 & Sleep Dealer & Alex Rivera \\
\hline \multirow{3}{*}{2009} & Hardwired & Ernie Barbarash \\
\hline & Tetsuo: The Bullet Man & Shinya Tsukamoto \\
\hline & Terminator: Salvation & McGinty Nichol \\
\hline \multirow{2}{*}{2010} & Repo Men & Miguel Sapochnik \\
\hline & Tren: Legacy & Joseph Kosinski \\
\hline \multirow[b]{2}{*}{2012} & Judge Dredd & Pete Travis \\
\hline & Total Recall & Len Wiseman \\
\hline \multirow{2}{*}{2013} & The Zero Theorem & Terry Gilliam \\
\hline & Elysium & Neill Blomkamp \\
\hline 2014 & Robocop & José Padilha \\
\hline 2015 & Terminator: Genisys & Alan Taylor \\
\hline \multirow{2}{*}{2017} & Blade Runner 2049 & Denis Villeneuve \\
\hline & Ghost in the Shell & Rupert Sanders \\
\hline \multirow{3}{*}{2018} & Upgrade & Leigh Whannell \\
\hline & Ready Player One & Steven Spielberg \\
\hline & Mute & Duncan Jones \\
\hline \multirow{2}{*}{2019} & Alita: Battle Angel & Robert Rodriguez \\
\hline & Terminator: Dark Fate & Tim Miller \\
\hline
\end{tabular}

Film listesi www.imdb.com adlı internet sitesinden oluşturulmuştur.

\section{Cyberpunk Temalı Filmlerin İncelenmesi}

Tablo-1'de yer alan Cyberpunk temalı filmler arasindan Blade Runner 2049, Ghost in the Shell ve Upgrade filmleri incelenmek üzere seçilmiştir. Bu filmler yakın dönemde vizyona girmiş olmaları, eşsiz görsel efektler barındırmaları, özel sahne tasarımlarına sahip olmaları ve günümüz teknolojisine benzerliklerinden dolayı seçilmiştir. Diğer filmlere oranla içerdikleri mekânlar, teknolojik nesneler günümüze yakın ve gelecek için daha olası tasarımları barındırmaktadır. Filmler göstergebilim metodu ile incelenmiş, kronolojik sıraya göre düzenlenmiştir.

Amerikalı filozof Charles Sanders Peirce'e göre göstergebilim ya da diğer adıyla semiyotik metodu kullanılırken üç ana parametre bulunmaktadır. Bunlar; Gösteren, Gösterilen ve Gösterge olarak sıralanmaktadır. Bu üç parametre yaygın olarak bir üçgen şeklinde şemalanmaktadır. Şekil 1'de yer alan üçgen şema bu çalışmaya göre uyarlanmıştır. 


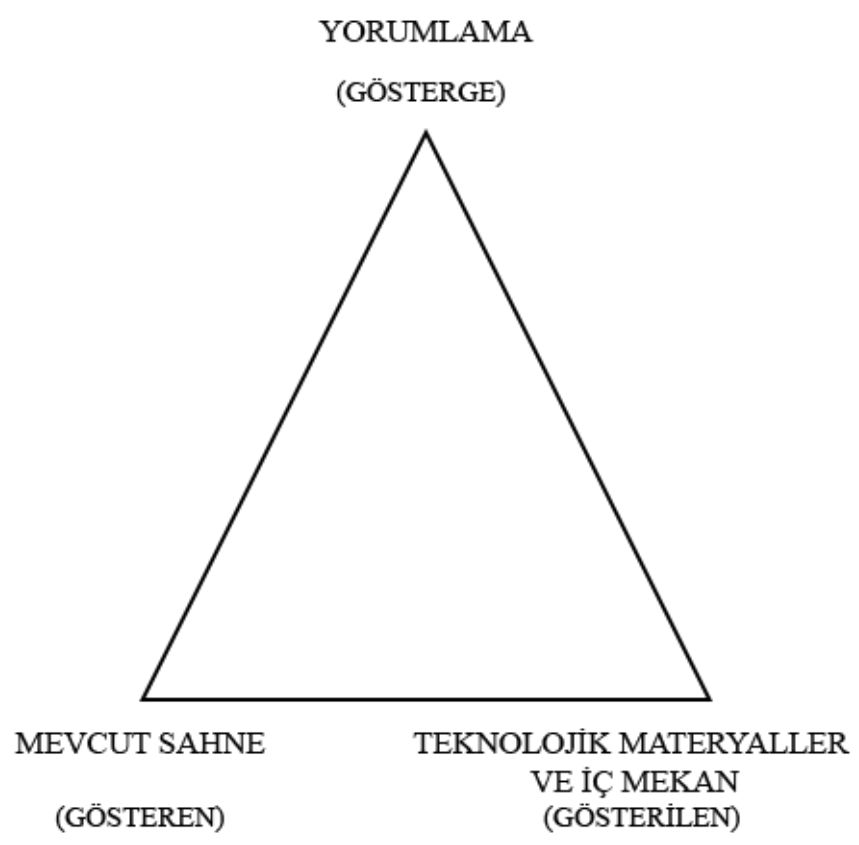

Şekil 1. Göstergebilim şemasının çalışmaya uyarlanmış hali.

\subsection{Blade Runner 2049 Filmi (2017)}

Cyberpunk türünün başyapıtları arasında gösterilen 1982 yapımı "Blade Runner" filminin devam niteliğinde olan 'Blade Runner 2049'” filmi 2017 y1lında vizyona girmiştir. Filmde ana karakter $K$, ilk filmdeki gibi toplum dışı kalmış Replikantları öldürmek ile görevlidir. İlk filmin devamında Replikantların bir isyan başlatması ve üretici olan Tyrell şirketinin batmasının ardından, Wallace şirketi yapay tarım ile insanlığı kurtarırken, tamamen itaat eden Replikantları da üretmeye başlamıştır.

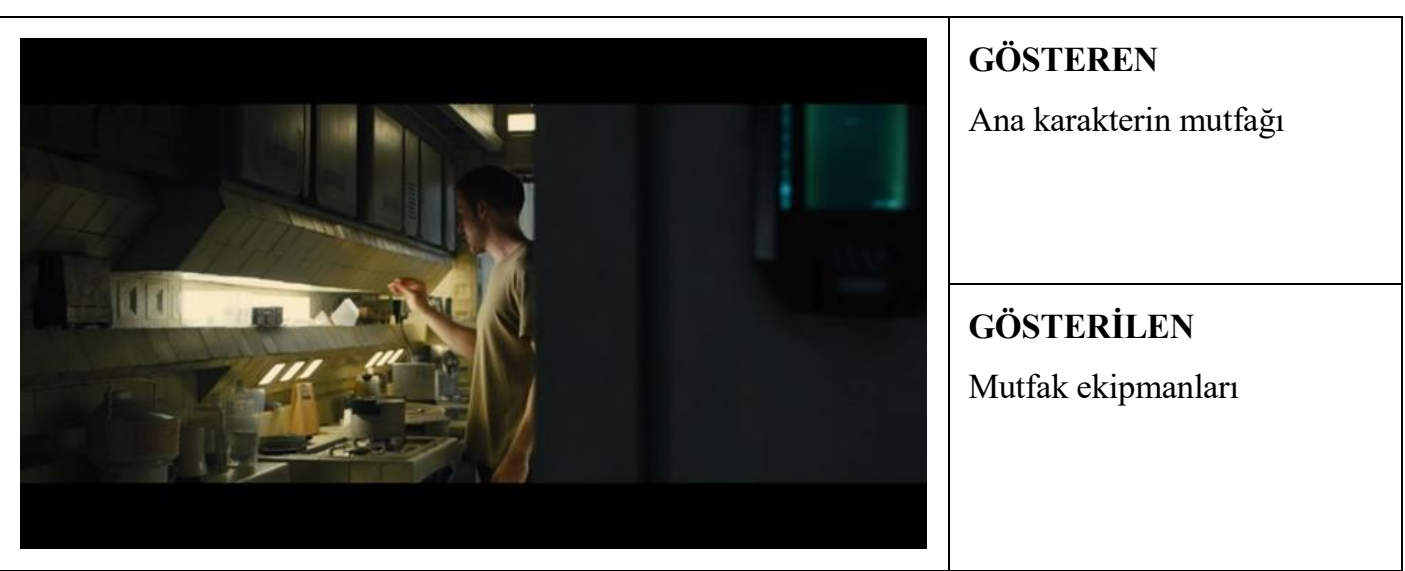

Resim 1. Ana Karakterin Mutfăğ . 


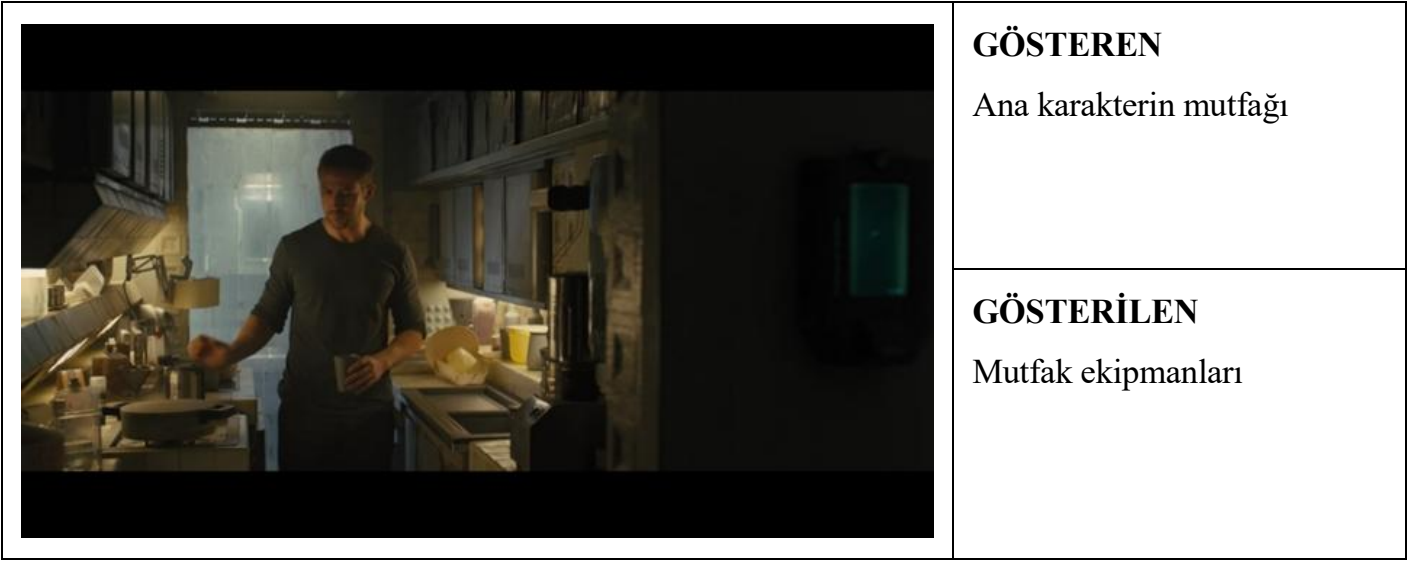

Resim 2. Ana Karakterin Mutfağı.

Resim 1 ve Resim 2'de ana karakterin mutfağ1 (gösteren) görülmektedir. Geleneksel tarzda mutfak dolapları yerine metal kutularda depolama birimleri kullanılmaktadır. Karşılıklı olarak konumlanmış tezgahlar, çalışma alanını oldukça daraltmaktadır. Mutfak dolabı olarak kullanılan metal kutular, mutfağın dar bir alana sahip olması insanların düşük yaşam kalitesine sahip olduklarını göstermektedir (gösterge). Filmde görülen mutfak elemanlarından ocak, eviye günümüz çizgisinde ve işlevde düşünülmüştür. Teknolojinin distopik bir boyutta geliştiği bu gelecekte, mutfak ekipmanlarının (gösterilen) günümüz çizgisinde olması alt tabaka insanların teknolojiye kolayca erişemeyeceğinin bir göstergesidir. Aydınlatmalar bölgesel olarak sınırlandırılmış ve beyaz ışık kullanılmıştır. Büyük bir pencereden şehrin karanlık, kasvetli gözüken havası, iç mekânda da yetersiz aydınlatmalar ve beyaz 1şıklar ile desteklenmektedir.
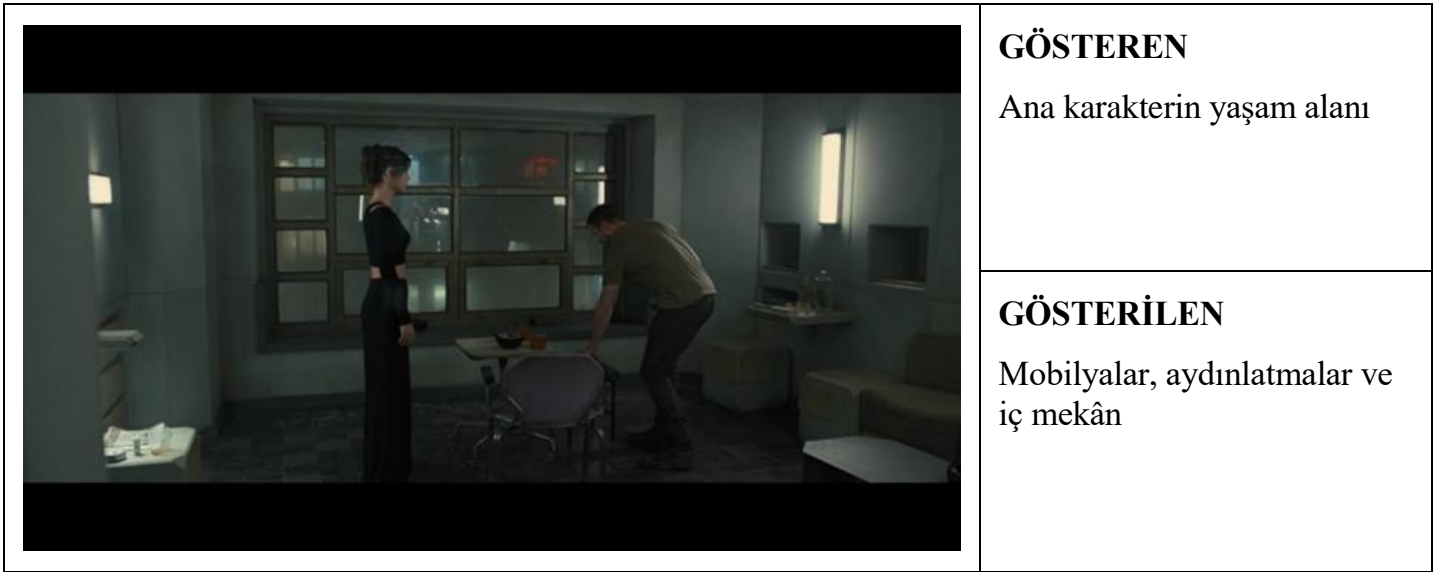

Resim 3. Ana Karakterin Yaşam Alanı.

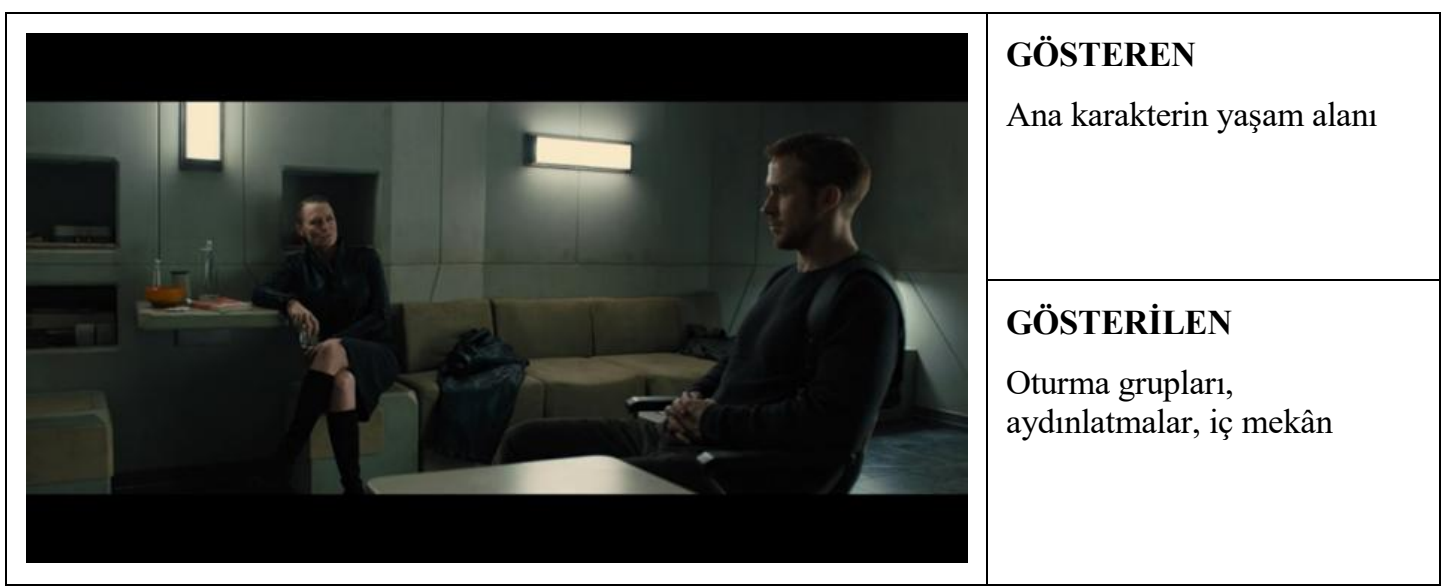

Resim 4. Ana Karakterin Yaşam Alanı. 
Resim 3 ve Resim 4 ana karakterin yaşam alanını (gösteren) göstermektedir. Mekân işleve yönelik olarak kısıtlı bir alana sahiptir. Mobilya sayısı olabildiğince az tutulmuştur. Minimal tarzda bir düzen mevcuttur. Depolama olarak kullanılan nişler, duvara sabit bir masa ve oturma elemanları, küçük boyutlarda bir masa ve oturma elemanı mevcuttur. Bu mobilyalar (gösterilen) süsten uzak, teknolojik işlevleri bulunmayan günümüz mobilyalarıyla benzerlik göstermektedir. Mekânın doğal ışık alması için büyük bir pencere konumlandırılmıştır. Mekânda soğuk bir izlenim yaratmak amacıyla soğuk renkler ve gri tonları kullanılmış, beyaz 1şık ile bu düşünce desteklenmiştir. Alt tabaka insanların iç mekân tasarımına özen göstermediği, oldukça kısıtlı mekânlarda hayatlarını sürdürdükleri görülmektedir (gösterge).

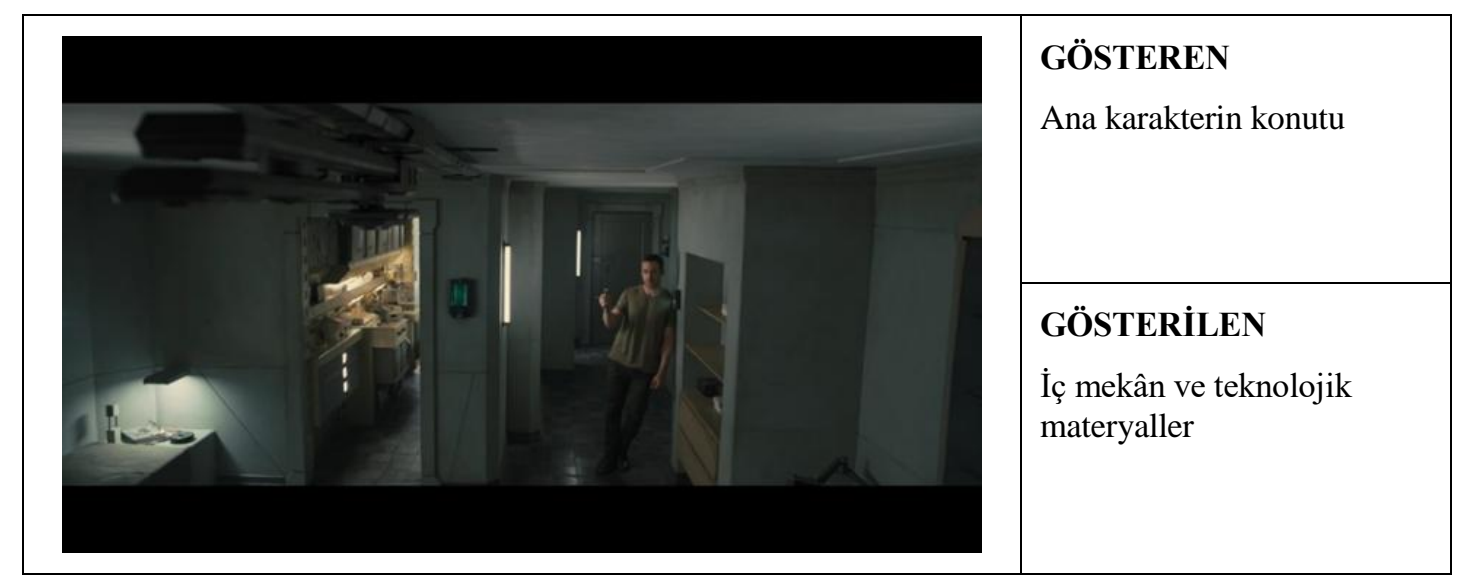

Resim 5. Geniş Açı Mutfak ve Giriş Kapısı.

Resim 5'te yer alan (gösteren) görsel, mekândaki genel tasarım anlayışını daha iyi görmemize olanak sağlamaktadır. Konutun kısıtlı alana sahip olduğu görülmektedir. Mekândaki soğuk ve tekdüzelik algısı, plan yapısında bulunan girinti ve çıkıntılarla eşitlenmektedir. Mutfak kapısının yanında bulunan akıllı kumanda merkezi ve tavanda bulunan hologram cihazı mekânda gelişmiş teknolojinin örneklerini (gösterilen) sunmaktadır. Gelecek yıllarda teknolojinin bu çizgide gelişimi, insan hayatının her alanında yer bulacağı bir gösterge niteliği taşımaktadır.

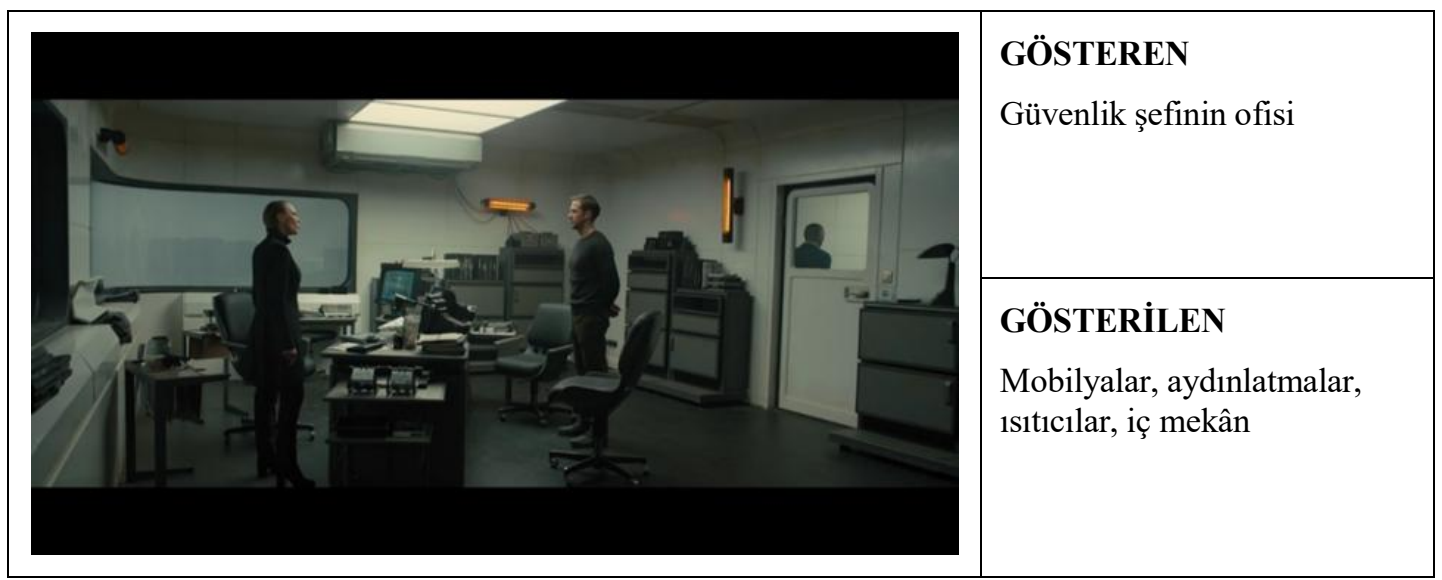

Resim 6. Güvenlik Şefinin Ofisi.

Resim 6'da yer alan görsel (gösteren) güvenlik şefinin ofisine aittir. Ana karakterin güvenlik şefinin karşısında duruşu hiyerarşinin güçlü olduğunun bir göstergesidir. Konutla aynı renk paletine sahip bu ofiste gri tonları kullanılmıştır. 2049 yılında geçen filmde, tüm insanların yüksek teknolojiye sahip olamadığı duvarlardaki ısıtıcılardan (gösterilen) anlaşılabilmektedir. İnsanların kötü koşullarda çalıştı̆̆ı belirtilmiştir (gösterge). Günümüzde kullanılan ısıtıcılarla aynı düzeydedirler. Minimalist mobilya tasarımlarının hâkim olduğu ofiste beyaz ışık ile soğuk bir izlenim yaratılmıştır. 


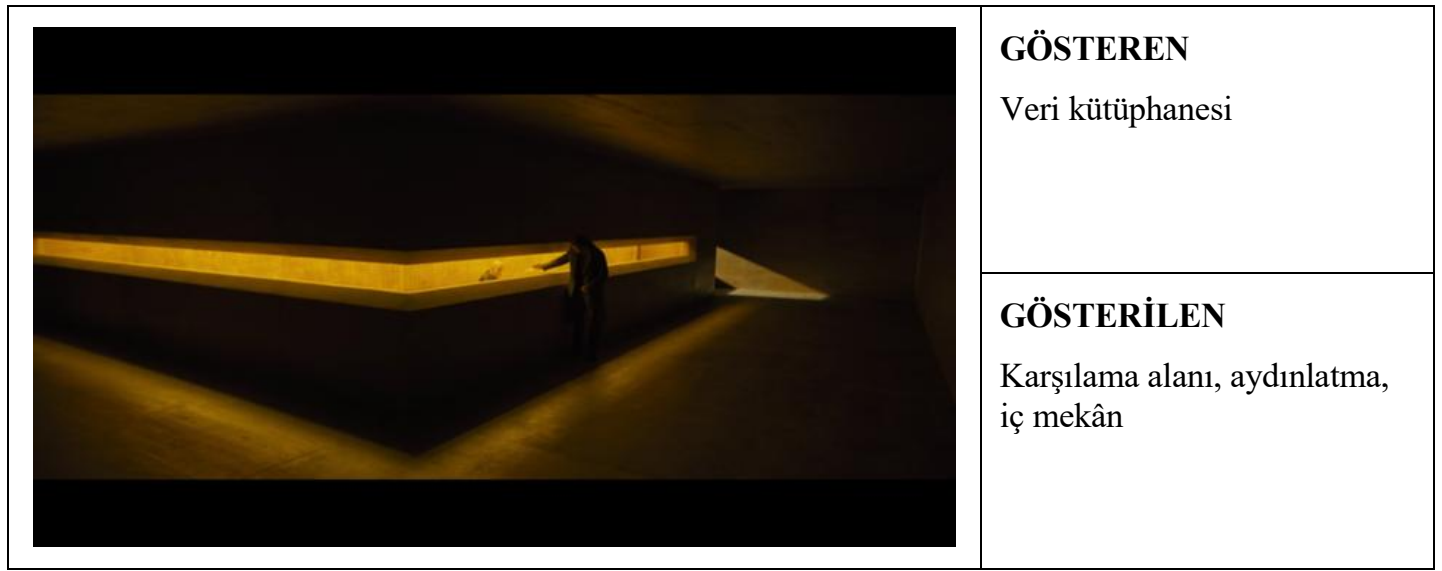

Resim 7.Veri Kütüphanesi Karşılama Alanı

Resim 7 ve Resim 8'de yer alan görseller, insanlara ait birtakım verilerin yer aldığı bir veri kütüphanesini (gösteren) göstermektedir. İnsanlardan gizli saklı işler yapan bir şirkete ait olan bu yapıda giriş alanından itibaren sarı 1şık (gösterilen) kullanılmaktadır. Buraya gelen insanın kendini güvende ve sakin hissetmesi için (gösterge) sarı 1şıklar oldukça yoğun bir şekilde kullanılmaktadır. Karşılama alanında büyük bir lobi bölümü yer alırken herhangi bir mobilya bulunmamaktadır. Buraya gelenlerin işlerini en kısa sürede halletmeleri düşünüldüğünden (gösterge) mekânların boş bırakıldığı görülmektedir.

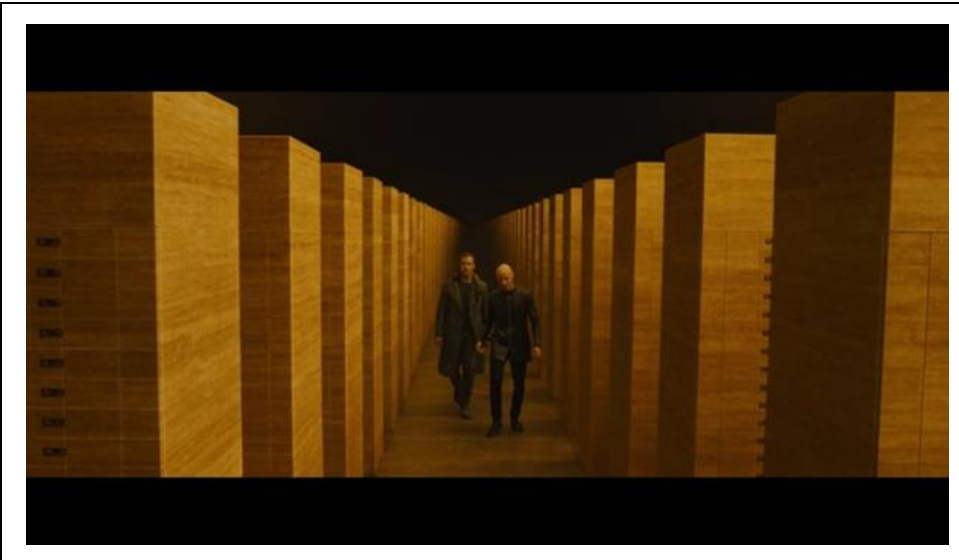

\section{GÖSTEREN}

Veri kütüphanesi

Resim 8. Veri Kütüphanesi.

Resim 9' da bulunan ofis (gösteren) su altında bulunmaktadır. Ofis minimalist bir çizgide düşünülmüş, fütüristik çizgide mobilyalara (gösterilen) sahiptir. Çalışma masasında bulunan ekran gizlenebilmektedir. Burada çeşitli görüşmelerin yapılmasından dolayı, bu mekânda da sarı 1şığın egemen olduğunu görmekteyiz. Görüşmeye gelen kişilerin kendilerini huzurlu ve güvenli hissetmeleri için ortamda sicak bir hava yaratıldığı (gösterge) görülmektedir. 


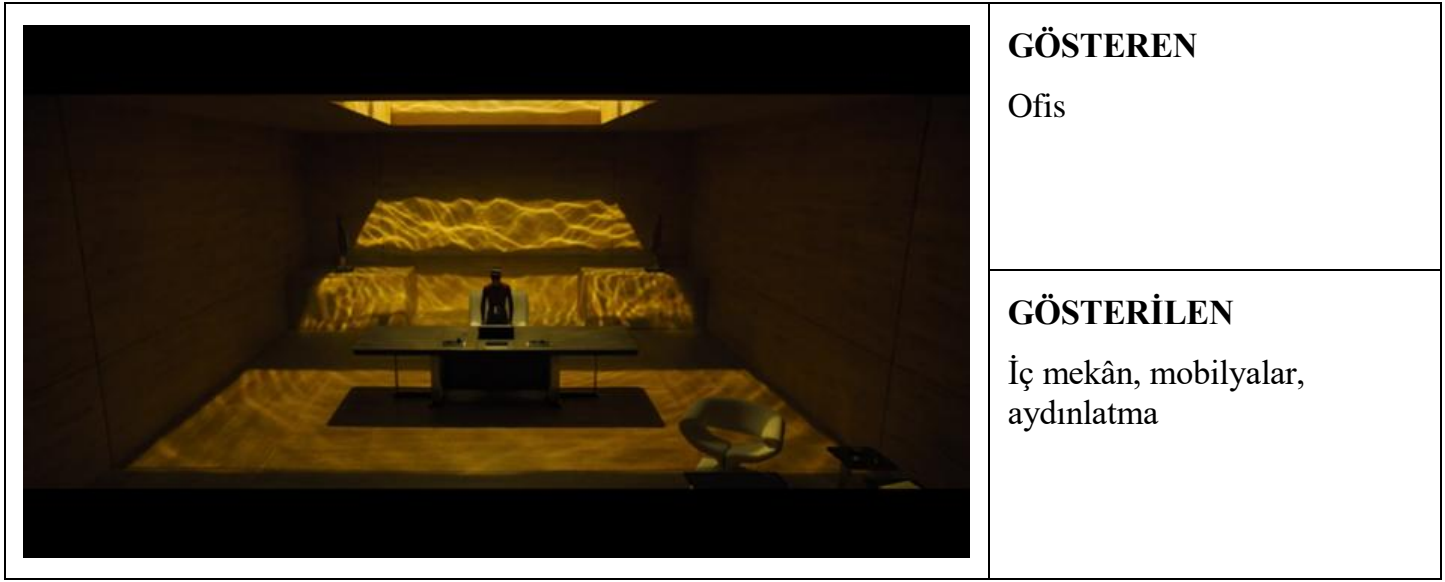

Resim 9. Su Altında Ofis.

\subsection{Ghost in the Shell Filmi (2017)}

2017 yılında vizyona giren film, Masamune Shirow'un mangasından uyarlanmıştır. Filmin konusu yakın bir gelecekte işlenmektedir. Teknoloji büyük bir hızla gelişmiş insan ve yapay zekâ arasındaki farklar giderek silikleşmeye başlamıştır. Teknolojik gelişmeler doğrultusunda insan beyni de yeniden yazılabilir ve hacklenebilir hale gelmiştir. Bir polis biriminin şefi olan Kusanagi bir cyborgtur ve hafizası silinmiştir. Beynine yapılan birkaç programlama dışında tamamen insandır. Vücudu makineler ile geliştirilmiştir. Film, kendini ve varoluşunu sorgulayan Kusanagi'nin bu süreçte yaşadıklarını anlatmaktadır.

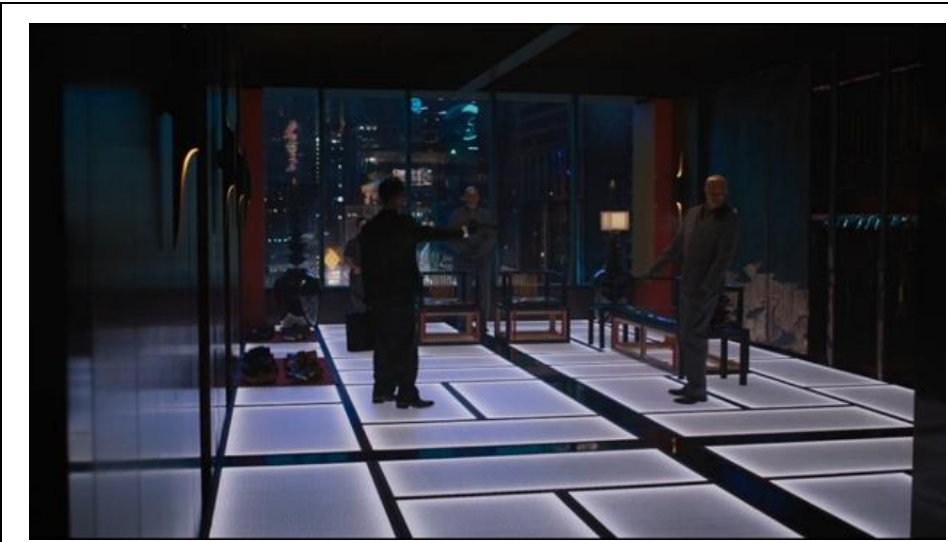

\begin{tabular}{|l|}
\hline GÖSTEREN \\
$\begin{array}{l}\text { Plazada yer alan toplantı } \\
\text { salonu giriş alanı }\end{array}$ \\
\hline GÖSTERILEN \\
$\begin{array}{l}\text { Aydınlatma, iç mekân, } \\
\text { kültürel ögeler }\end{array}$ \\
\hline
\end{tabular}

Resim 10. Toplantı Salonu Girişi.

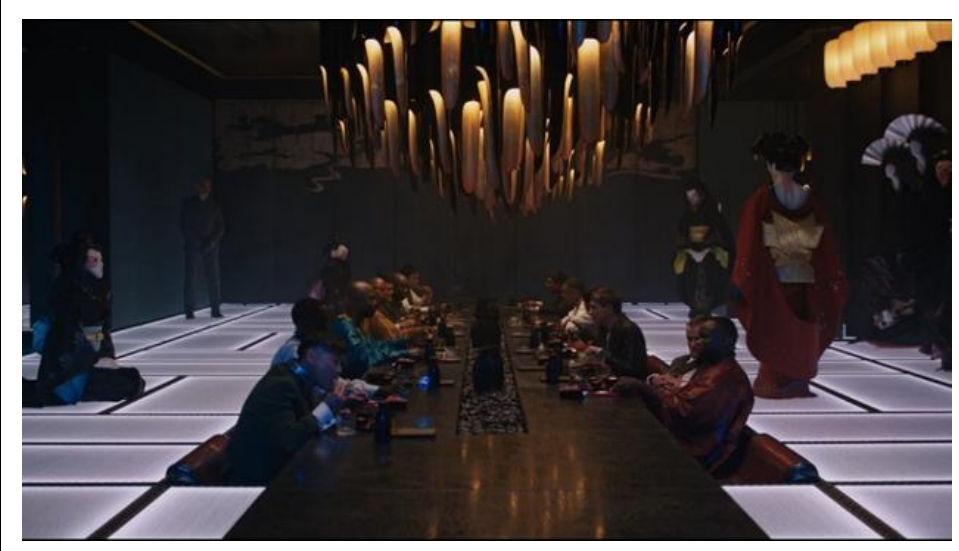

\section{GÖSTEREN}

Toplantı salonu

\begin{tabular}{|l|} 
\\
\hline GÖSTERILEN \\
İç mekân, aydınlatma, \\
kültürel ögeler
\end{tabular}

Resim 11. Toplantı Salonu. 
Resim 10 ve Resim 11'de yer alan sahneler, önemli sayılan yöneticiler ve başkanların toplantı yaptı̆̆ bir yapıdır (gösteren). Resim 10'da minimalist mobilyaların kullanıldı̆̆ bekleme alanı görülmektedir. Japon kültürünü yansıtan figürler göze çarpmaktadır. Koyu ve soğuk renkler tercih edilirken, aydınlatma olarak zeminde uygulanmış beyaz ışı̆̆ın kullanıldığı (gösterilen) görülmektedir. Bu veriler doğrultusunda mekânda soğuk, ürpertici, karanlık bir izlenim yaratılmak istenmiştir (gösterge). Büyük bir yapıda yer alan bu toplantı salonu üst tabaka insanların geldiği güvenlikli bir yapı özelliği taşımaktadır. Resim 11 'de büyük bir toplantı masası zemin kotuna oldukça yakın yükseklikte yer almaktadır. Japon kültürüne ait bir şekilde oturma elemanları zemin kotundan alt kotlarda konumlandırıldığı dikkat çekmektedir (gösterilen). Aynı tarzda Japon figürleri, koyu ve soğuk renkler tercih edildiği görülmektedir. Zeminde uygulanan beyaz ışığın yanı sıra, oldukça büyük boyutlarda avizeler ve Japon kültürüne uygun bölgesel aydınlatmalar bu kez sarı 1şık olarak yer almaktadır. Mekânda bulunan maskeli robotlar kullanıcılara hizmet etmektedir. Gelecek yıllarda insanların toplantılar için yüksek güvenlikli mekânlar tercih edecekleri, yapay zekaya sahip robotların kullanılacağı bir gösterge niteliği taşımaktadır.

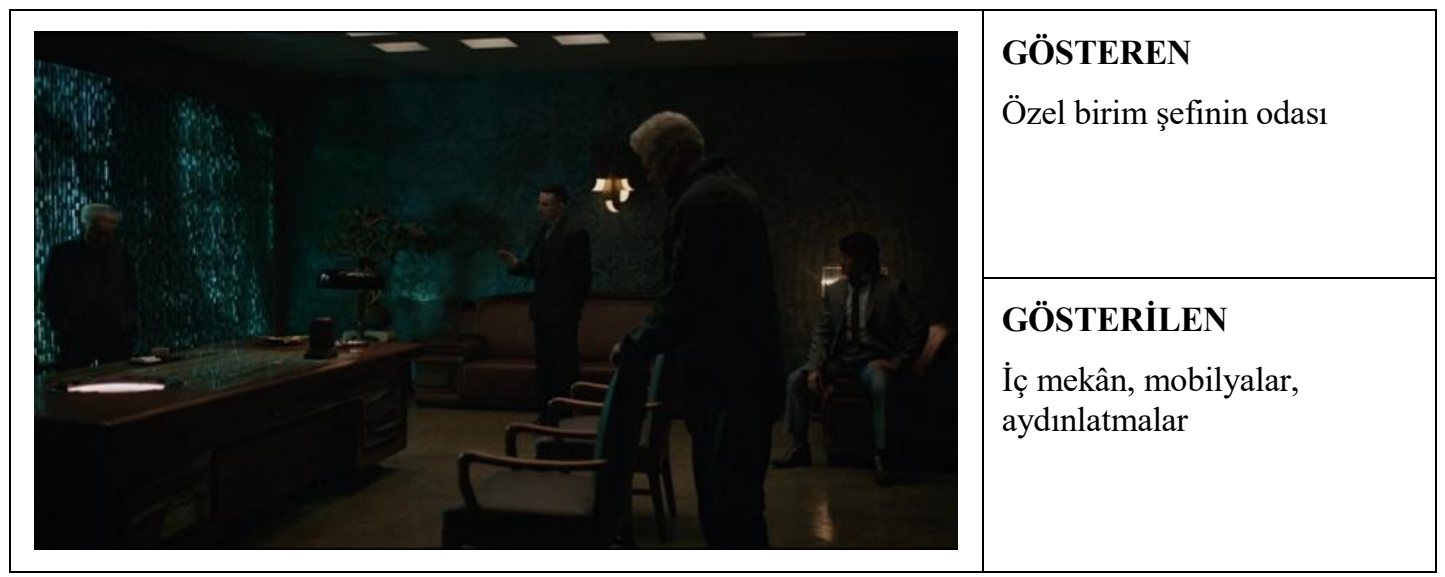

Resim 12. Birim Şefinin Odası.

Resim 12'de yer alan sahnede özel polis biriminin şefinin odası (gösteren) görülmektedir. Mobilyalar günümüz mobilyalarıyla benzerlik göstermektedir (gösterilen). Ahşap iskelet ve deri kaplama kullanıldığı görülmektedir. Görselde yer alan insanların güvenlik şefi ile bir görüşme halinde olduğu ve gergin bir ortam olduğu görülmektedir. Aydınlatma bölgesel olarak düşünülmüş olup, beyaz ışık çoğunlukta yer almaktadır. Kahverengi ve yeşil renkler ile birlikte mekân soğuk, karanlık ve gizemli görülmektedir. Mekân genel olarak teknolojiden bağımsız, geleneksel bir tarza sahiptir.

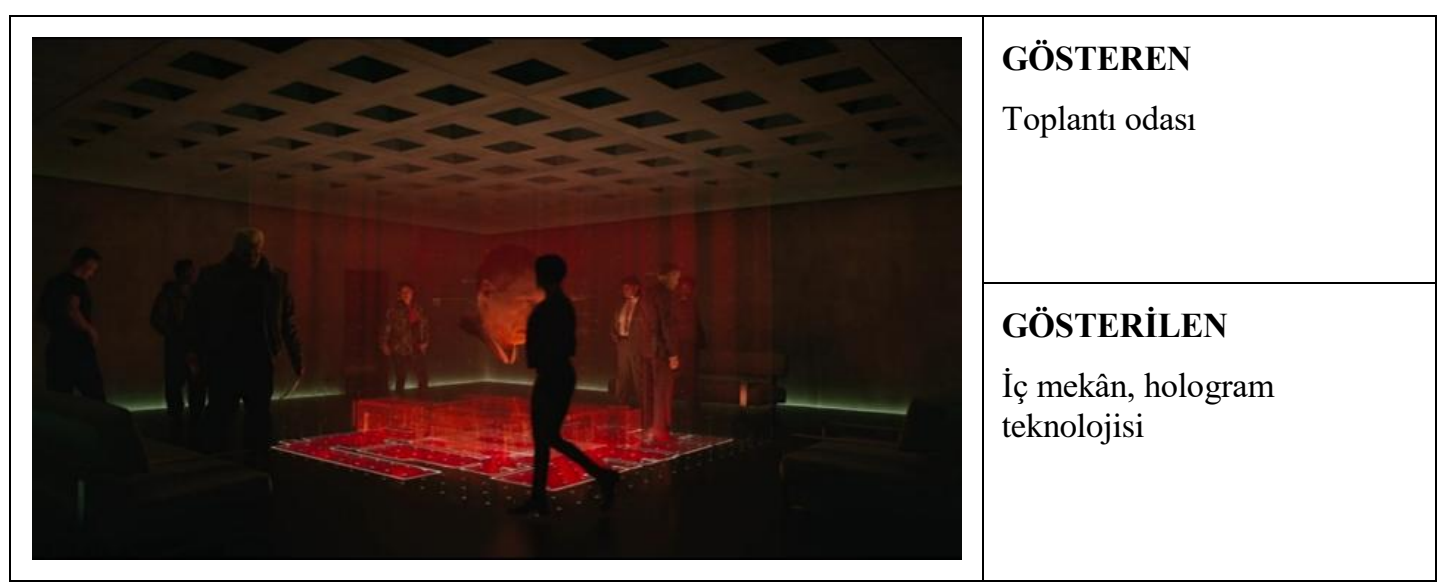

Resim 13. Brifing Odasl.

Resim13'de görülen polis biriminin brifing odası (gösteren) tamamen karanlık bir oda olarak tasarlanmıştır. Odanın ortasında büyük bir hologram sistemi (gösterilen) mevcuttur. Bu sistem ile görüşmeler, planlar hologram olarak yapılmaktadır. Modern tarzda oturma birimleri mevcut olup; süpürgelikleri çevreleyen neon yeşil aydınlatma göze çarpmaktadır. Toplantıya katılanların ayakta olması, telaş içinde olduklarının bir göstergesidir. Aydınlatmaya sahip olmayan mekân sadece 
hologramın 1şıkları ile aydınlatılmaktadır. Teknolojinin insan hayatında yeri, gelecek yıllarda özellikle savunma alanlarında oldukça fazla kullanılacağı bir gösterge niteliği taşımaktadır.

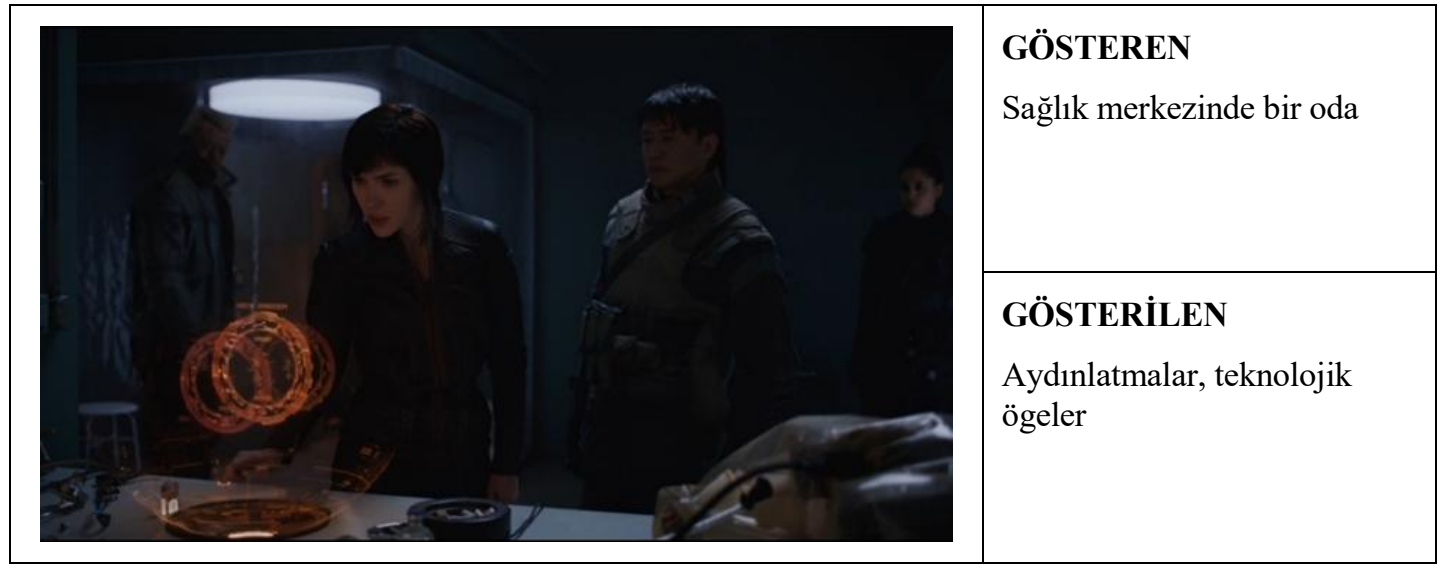

Resim 14. Să̆llk Merkezi.

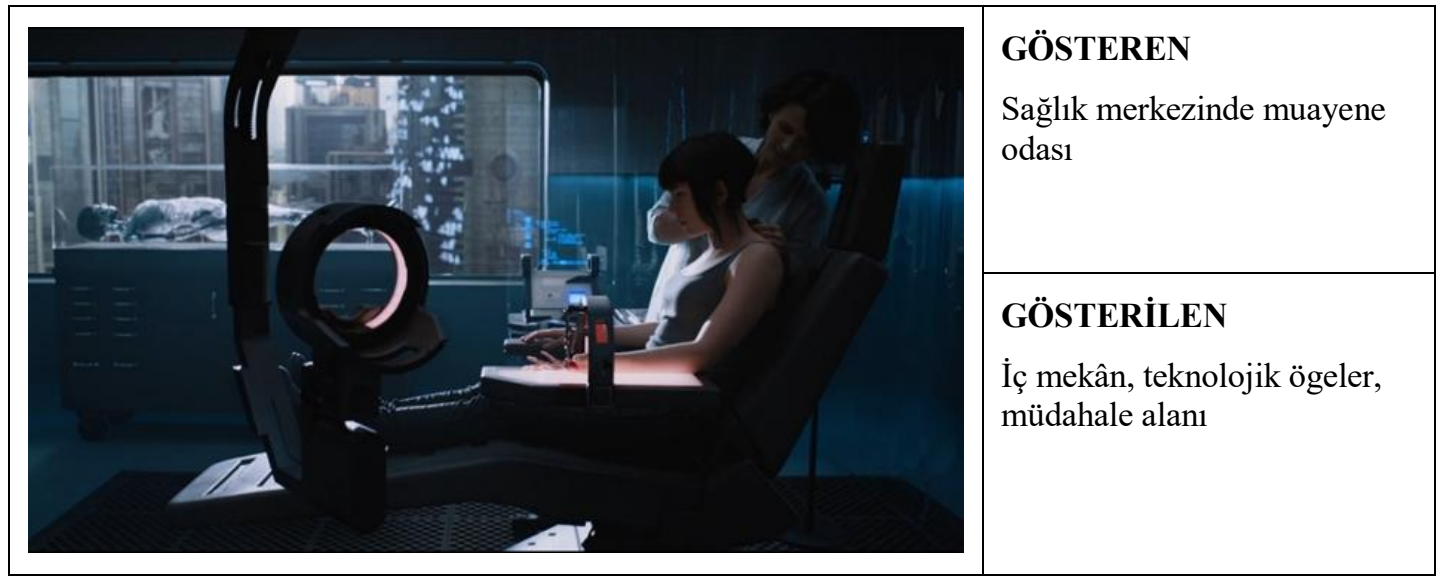

Resim 15. Să̆lık Merkezi Muayene Alanı.

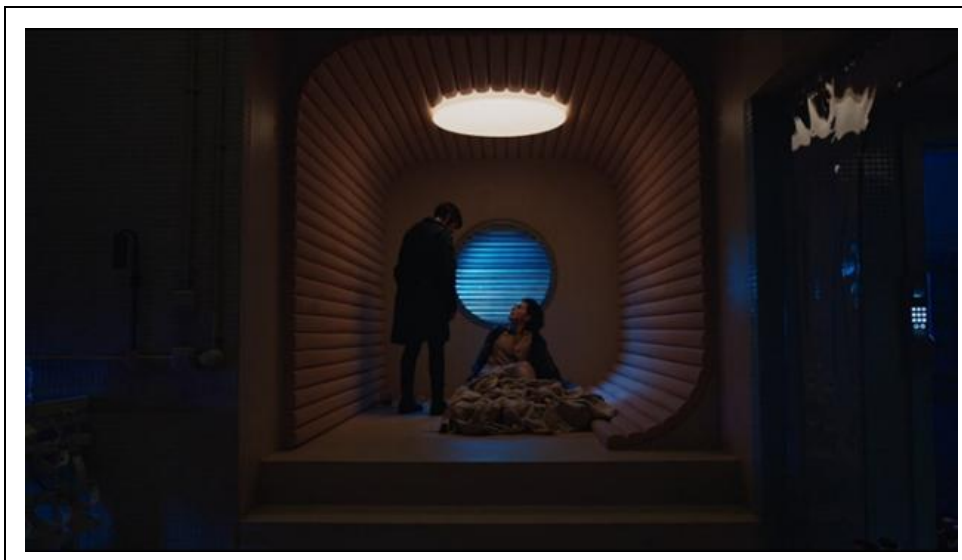

\section{GÖSTEREN}

Yatak alanı

Resim 16. Să̆glk Çalışanının Yatma Alanı.

Resim 14 ve Resim 15 sağlık merkezini (gösteren) göstermektedir. Resim 14' te masaya entegre bir hologram cihazı (gösterilen) görülmektedir. Masa üzerinden kontrol edilebilen bu sistem, teknoloji ile mobilyanın bu noktada birleştiğini göstermektedir. Gelişmiş teknolojinin mobilya tasarımına da etki ettiği görülmektedir. Daire formunda beyaz 1şıklı aydınlatma göze çarpmaktadır. Resim 15 ana karakterin muayene olduğu sahneden alınmıştır. Muayene koltuğu form olarak günümüzde kullanılanlardan farksızdır. Ancak işlev ve teknolojik değişiklikler (gösterilen) mevcuttur. Mekânda büyük pencereler mevcut olmasına rağmen, mavi ve gri tonları mekânda soğuk ve karanlık bir izlenim yaratmaktadır. Arka planda kuvözün içinde yer alan robot, gelişmiş teknolojinin bir getirisi olan ürperti 
ve korku hissini (gösterge) uyandırmaktadır. Pencereden gözüken şehir temasında oldukça yüksek yapılar yer almaktadır.

Resim 16 sağlık çalışanın konutunda bulunan yatak alanını (gösteren) göstermektedir. Daire formunda pencere ve aydınlatma Japon kültürünün bir yansıması olarak karşımıza çıkmaktadır. Yatma mekânı olduğu için, dinlendirici, rahatlatıcı etkisi nedeniyle sarı 1şık (gösterilen) kullanılmaktadır. Teknolojik kumanda merkezi, soğuk renkler mekâna fütüristik bir izlenim (gösterge) katmaktadır.

\subsection{Upgrade Filmi (2018)}

Upgrade, bir kaza geçiren ve bu kaza sonrasında belden aşağısı felç kalan ana karakter Grey'in intikamını işleyen bir filmdir. Omurgasına yerleştirilen bir implant ile vücudu fonksiyonlarını geri kazanmaktadır. İmplant yapay zekaya sahip bir canlı konumundadır ve zamanla ana karakterimizin vücudunu kendi kontrolü altına almaktadır. İnsan zekâsı ve yapay zekasının çatışmasının yaşandığı bu film Cyberpunk türüne iyi bir örnek teşkil etmektedir.

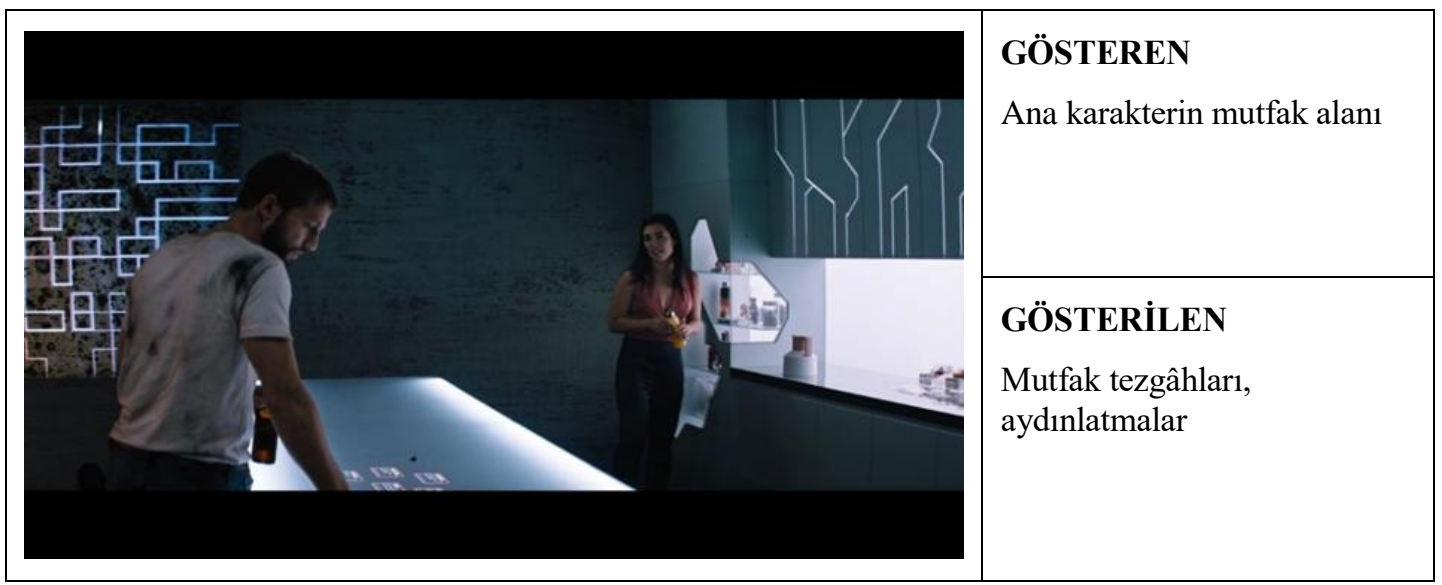

Resim 17. Filmin Ana Karakteri Grey'in Mutfă̆ı.

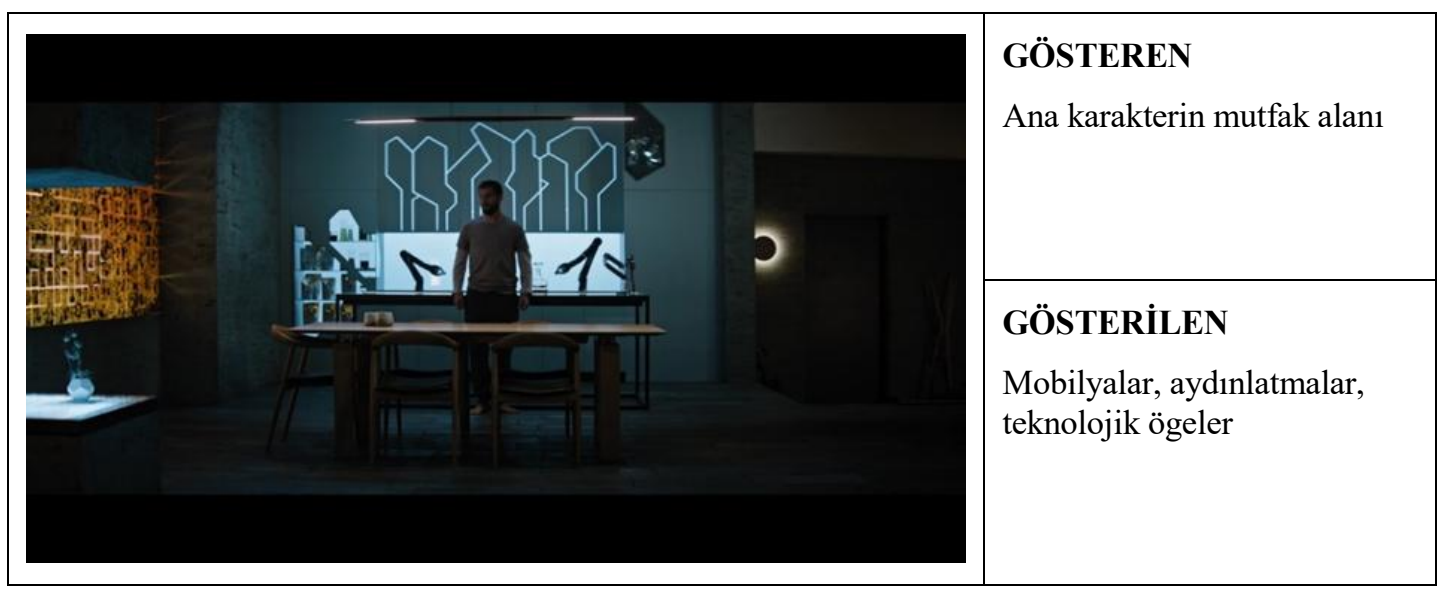

Resim 18. Filmin Ana Karakteri Grey'in Değişmiş Mutfă̆g.

Resim 17 ve Resim 18'de ana karakterin konutundaki mutfak (gösteren) görülmektedir. Resim 17 filmin başlangıcında görünen mutfaktır. Ada mutfak tipinde düzenlenmiş oldukça fütüristik bir çizgiye sahip olan mutfakta ada tezgâhın üstünde iletişim, bilgisayar fonksiyonlu bir dokunmatik ekran entegre (gösterilen) durumdadır. Ana karakterin bu tezgâh alanında mesajlarını okuduğu görülmektedir. Mutfak beyaz renk, beyaz 1şık ve brüt beton ile soğuk bir mekân olarak göze çarpmaktadır. Resim 18 'de mutfak tezgahına eklenen 3 adet robot kol (gösterilen) görülmektedir. Filmin ilerleyen sahnelerinde değişen mutfakta yer alan bu kollar, felçli olan karakterin yemek, içecek gibi ihtiyaçlarını karşılayan ve ilaçlarını uygulayan robotlardır. Gelişmiş teknolojinin günlük hayatta her alanda karşımıza çıkacağ 1 ve insanların teknoloji ile her noktada kaynaşacağını (gösterge) anlatmaktadır. 


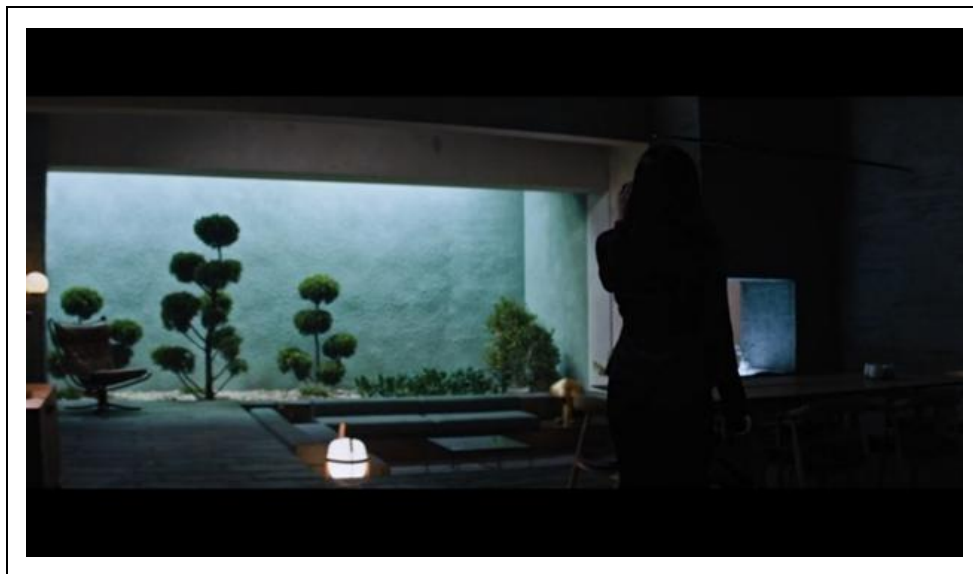

\begin{tabular}{|l|}
\hline GÖSTEREN \\
Ana karakterin yaşam alanı \\
\hline $\begin{array}{l}\text { GÖSTERILEN } \\
\text { İç mekân, mobilyalar, } \\
\text { aydınlatmalar, beton-doğa } \\
\text { ilişkisi }\end{array}$ \\
\hline
\end{tabular}

Resim 19. Filmin Ana Karakteri Grey'in Salonu.

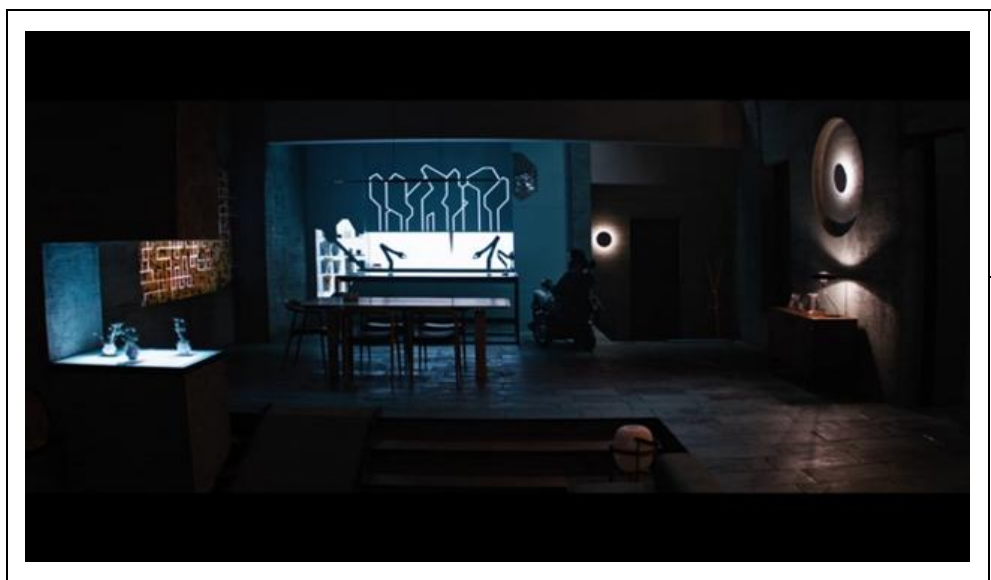

\section{GÖSTEREN}

Ana karakterin konutu

Resim 20. Salon ve Mutfak Geniş Açıdan Görülmektedir.

Resim 19 ve Resim 20 ana karakterin evinin salonunu (gösteren) göstermektedir. Salon olarak belirlenen alanda oturma alanının kot farkı ile belirtilmiş olduğu görülmektedir. Günümüzde kullanılan mobilyalara benzer tarzda mobilyalar (gösterilen) mevcuttur. Mekân brüt beton olarak tasvir edilmektedir. Arkada yer alan kış bahçesinde doğanın beton ile uyumu gösterilmektedir. Yaşam koşullarının da değişmesi ile birlikte artan betonarme yapıların doğa ile iç içe yaşaması gerektiğine ve diğer yandan teknoloji ile insanın birlikte yaşamak zorunda olduğuna (gösterge) vurgu yapılmaktadır.

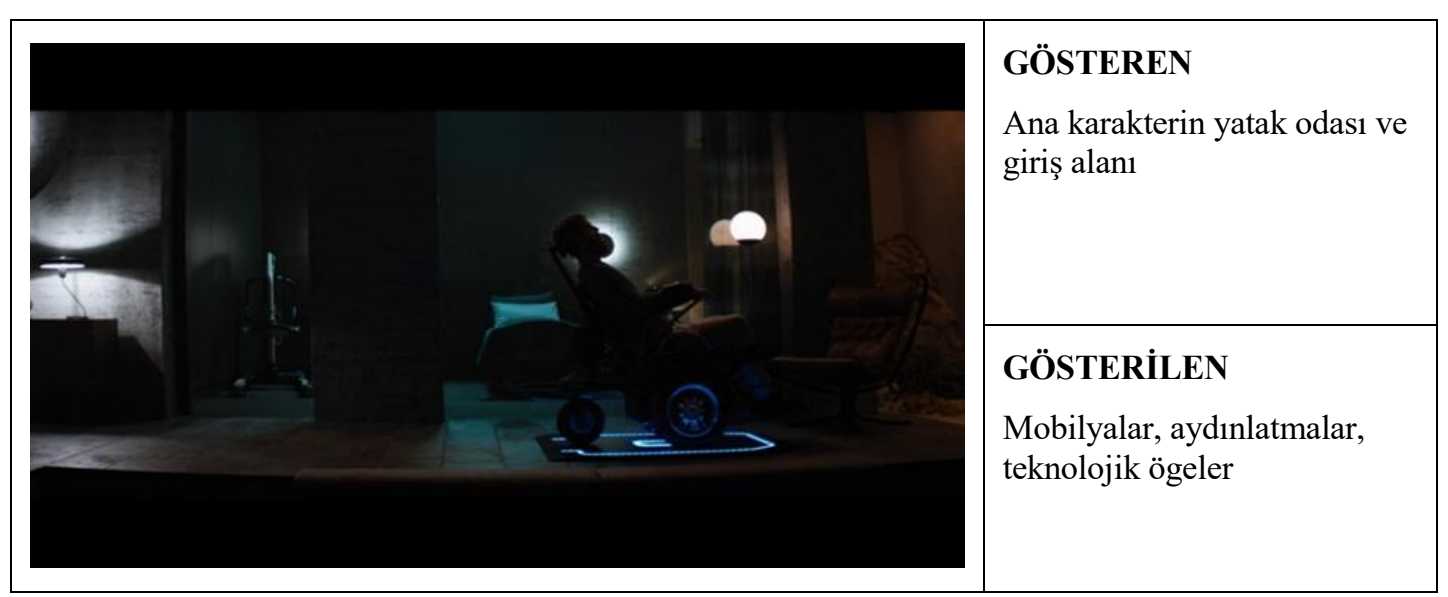

Resim 21. Yatak Odası ve Girişi.

Resim 21 ana karakterin yatak odasının (gösteren) bulunduğu bir sahneden alınmıştır. Yatak odasının önünde zeminde, sandalyesini şarj etmek için bir şarj ünitesi (gösterilen) bulunmaktadır. Brüt beton etkisi beyaz ve bölgesel 1şıklarla desteklenmektedir. Mekân tamamen soğuk bir ortam algıs1 
yaratmaktadır. Mekânın yarattığı bu etkiler ana karakterin yaşadığı yalnızlığı ve öfkeyi de bir anlamda (gösterge) desteklemektedir. Konutta en az sayıda mobilya kullanımı görülmektedir.

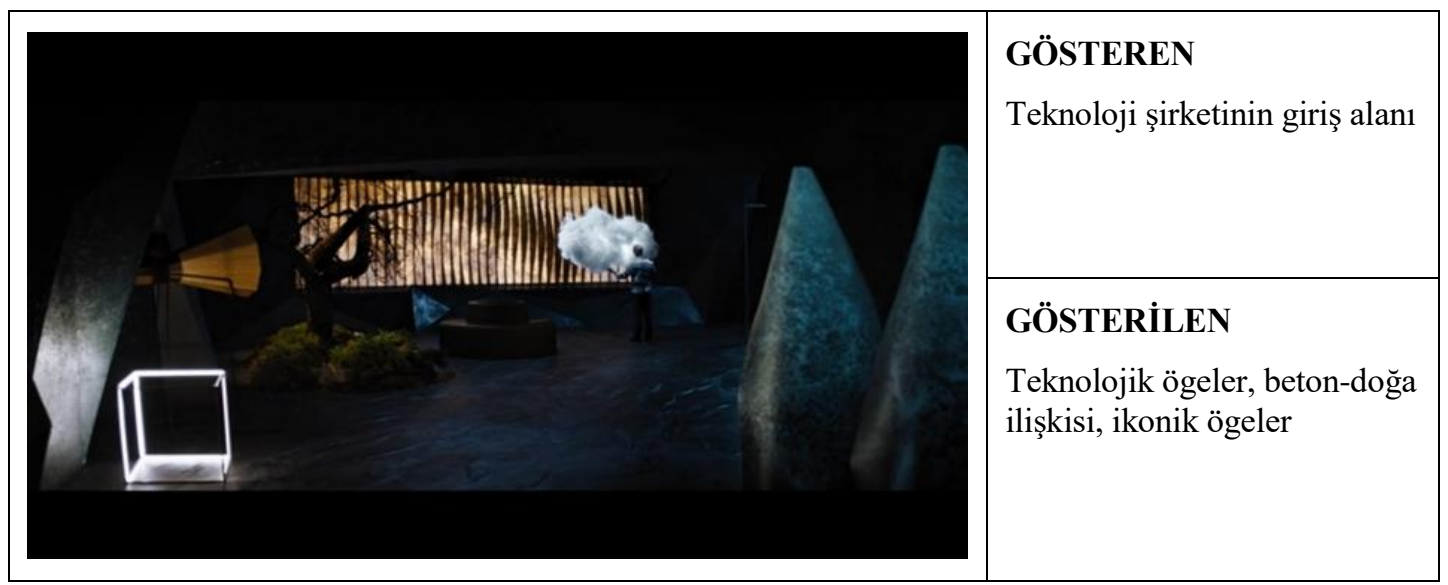

Resim 22. Teknoloji Şirketinin Ofisi.

Resim 22' de yer alan görselde ofisin giriş alanı (gösteren) görülmektedir. Fütüristik çizgide bir tasarım anlayışı mevcuttur. Soyut heykellerin de yer aldığı bu mekân (gösterilen), sahibinin iç dünyasını izleyicilere yansıtmaktadır. Teknolojik nesnelerin yer aldığ 1 görselde beyaz 1 şık ve sarı $1 s ̧ 1 k$ kullanılmaktadır. Ofisin içinde doğa ile iç içe olan bahçeler yer (gösterilen) almaktadır.

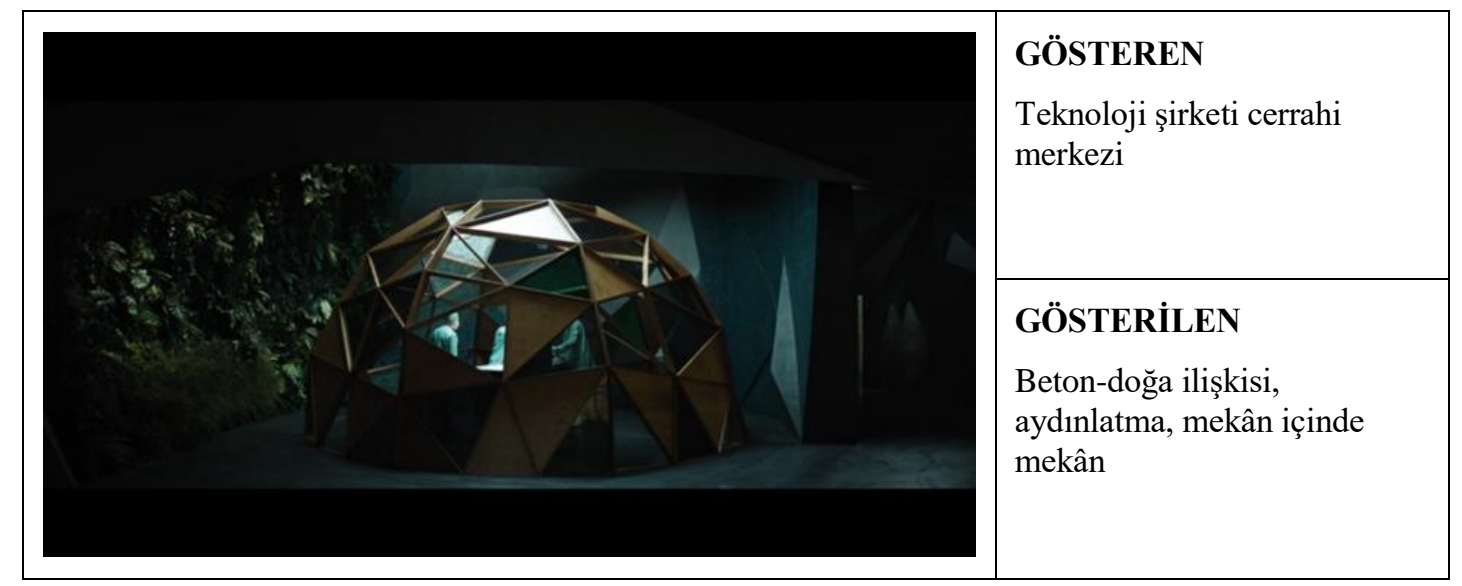

Resim 23. Teknoloji Şirketi- Cerrahi Merkezi.

Resim 22 ve Resim 23'te yer alan sahneler teknoloji devi olan bir şirketin yer altındaki ofisine (gösteren) aittir. Bu mekânlar brüt betonu, griyi ve tonları kullanmaktadır. Beton ile doğa birleşimini çok iyi bir şekilde anlatmaktadır. Geleceğin dünyasında doğa ile iç içe yaşamak zorunda olunduğunun bir göstergesi olarak karşımıza çıkmaktadır. Beyaz 1şıkların çoğunlukta olduğu mekânda sarı ışıklar da (gösterilen) yer almaktadır. Modern mimarinin etkisi altında olduğu görülmektedir. Mekân içinde mekân yaratılmış (gösterilen) ve cerrahi müdahale alanı olarak kullanılmaktadır.

\section{Cyberpunk Temalı Gerçek Mekân Örnekleri}

Cyberpunk, edebiyat ve sinema başta olmak üzere, illüstrasyon, müzik, video oyunları gibi alanlarda mevcut olmasına rağmen günümüzde tam anlamıyla benimsenmiş konumda değildir. Cyberpunk türünde filmlerde yer alan iç mekânlar ve mimari yapılar fütüristik ve modern çizgide tasarlanmaktadır. Teknolojik ögelerin, neon ışıkların yer aldığı mekânlar bu tür için yeterli bir tasarım anlayışı ortaya koymamaktadır. Belirli karakteristik özellikleri olmasına rağmen hala gelişilmekte olan Cyberpunk türü mimari ve iç mekân tasarımında kendine yer edinememiştir.

Haziran 2018 tarihinde Amerika'da gerçekleşen E3 konferansında tanıtılan 'Cyberpunk 2077' isimli oyun büyük ses getirmiştir. Tanıtım ve reklam amacı ile mekân tasarımları yapılmıştır. Oyunu deneme imkânı bulunan bir mekân, bar, toplantı salonu gibi mekânlar tasarlanmıştır. 


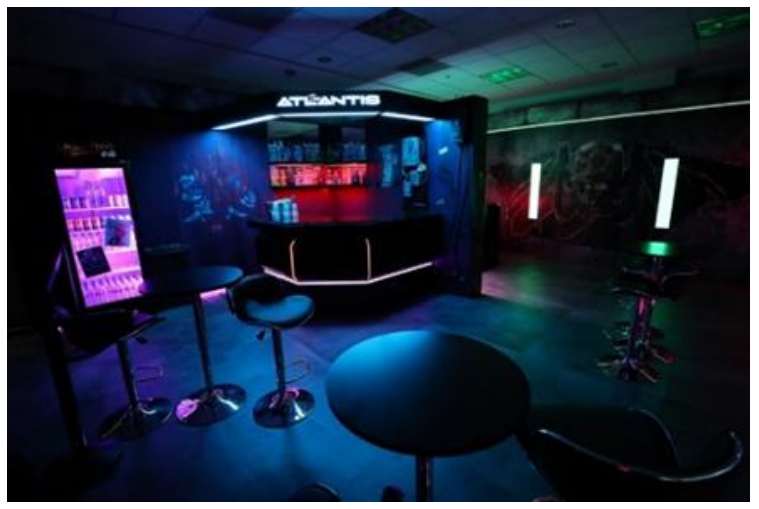

Resim 24. Cyberpunk Özellikleri Taşıyan Bar Mekânı.

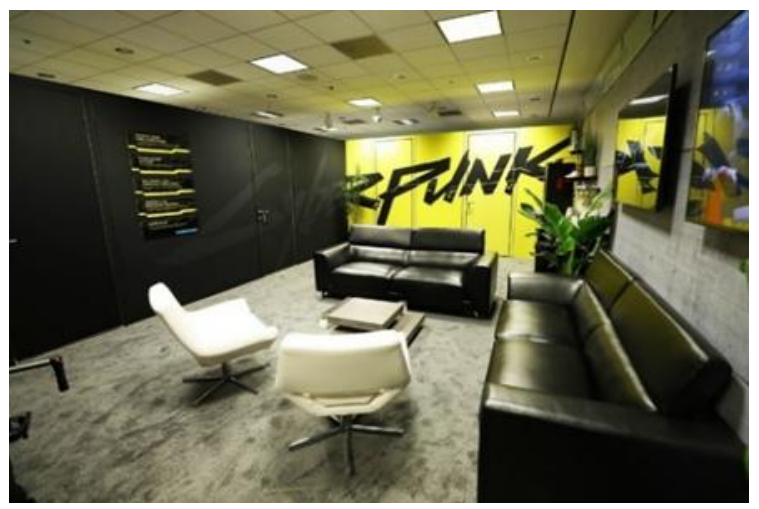

Resim 25. Cyberpunk Özellikleri Taşlyan Ofis Mekânı.

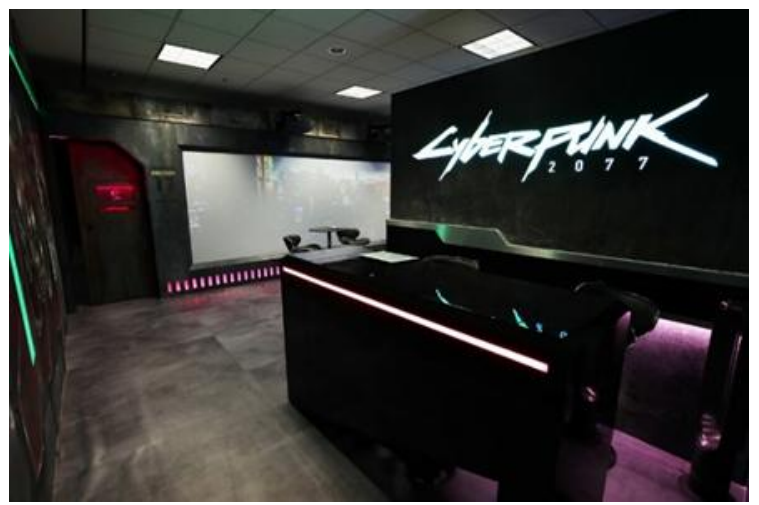

Resim 26. Cyberpunk Özellikleri Taşlyan Oyun Alanı.

Cyberpunk ögeleri barındıran oyunun tanıtımı için tasarlanan bu mekânlarda siyah rengin hâkim olduğu görülmektedir. Cyberpunk türünün yadsınamaz bir gerçeği olarak mor, mavi gibi neon ışıklar yanı sıra mobilyaların modern ve fütüristik çizgide tasarımlara sahip olduğu görülmektedir. Bu mekânlar fuara katılan oyuncu ve temsilcilerin dikkatini çekmek, onlarda bir heyecan yaratmak amacıyla tasarlanmıştır. 


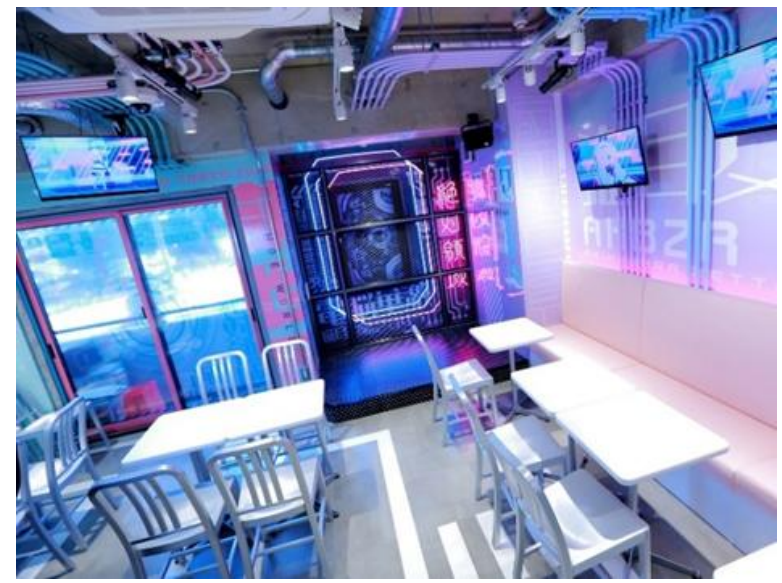

Resim 27. Akiba Zettai Ryoiki Kafe.

Japonya Tokyo'da bulunan Akihabara bölgesi, Elektrik Kenti unvanı ile anılmaktadır. Resim 27'de, bu bölgede Mart 2019 yılında açılan bir kafeterya mekânı görülmektedir. Kafeteryanın işletmecisi Yousuke Yamamato; ' 'Bu bölgede çok sayıda Cyberpunk türü hayranı mevcut, bu yüzden Blade Runner ve Ghost in the Shell gibi anime filmlerinden ilham aldık." demiştir ('Inside the world's", 2020). Mekânda beyaz renk ve pastel tonlar tercih edilmiş, neon 1şıklar, televizyon ekranları yer almaktadır. Cyberpunk türünde müziklerin çaldığı mekânda, minimalist mobilyalar tercih edilmiştir.
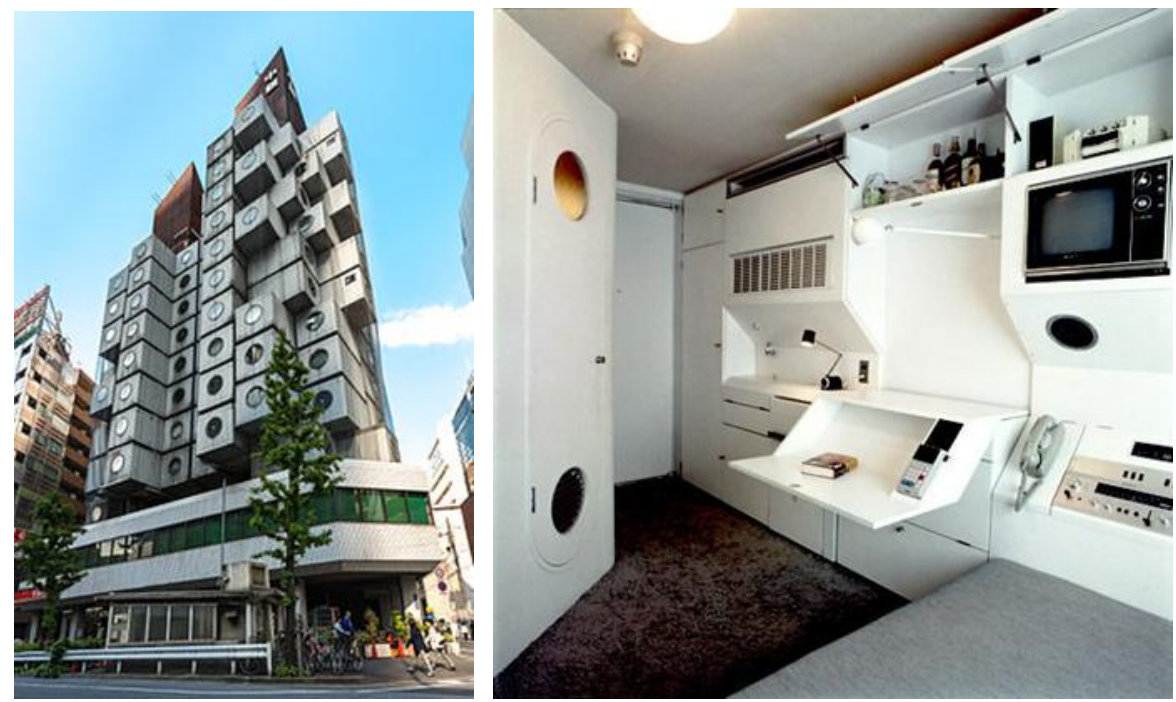

Resim 28. Nakagin Kapsül Kulesi.

Resim 28'de görülmekte olan Nakagin Kapsül Kulesi Japonya'nın başkenti olan Tokyo'da yer alan çok amaçlı bir konut yapısıdır. 1972 yılında 30 gün içerisinde inşa edilmiştir. Yapı, devamlı ve pratik kullanıma uygun olarak dünyanın ilk kapsül mimari örneğidir. Yapının mimari özellikleri Cyberpunk türüne bir örnek teşkil etmemektedir. Ancak kapsüllerin asgari alanlara sahip olması, kapsül içindeki mobilyaların işlevleri ve tasarımları Cyberpunk türüne örnek olabilecek şekildedir. Nüfusun ve şehirleşmenin artması, ekonomik nedenler insanları bu mekânlara yöneltmektedir.

\section{Bulgular}

İncelenen filmler Cyberpunk türüne örnek olarak gösterilecek önemli filmlerdir. Üç film de senaryo, hikâye, karakterlerin iç dünyaları ve toplum düzenleri açısından Cyberpunk türünde gösterilmektedir. Cyberpunk'ın içerdiği teknoloji, yapay zekâ, insan-makine birleşimleri, android robotlar filmlerde mevcuttur. Teknolojinin yarattığı olumsuz etkiler, insanların yaşayışlarında göze çarpmaktadır. Ülkelerin yönetimleri, teknoloji devi şirketlerin çok güçlü konumlarda olmalarından bahsedilmektedir. Filmlerde sokak hayatı, şehirleşme ve yapıların çoğunda yer alan teknolojik reklamlar göze çarpmaktadır. 
Cyberpunk türü gelişen teknoloji ile insanların arasındaki uyumu ve bu uyumun bir zorunluluk olduğunu göstermektedir. Filmler genellikle soğuk, karanlık, gizemli ortamlarda geçmektedir ve teknolojinin insan ve toplum üzerinde yarattığı kötü etkileri bu şekilde yansıtmaktadır.

"Blade Runner 2049" filminde hikâye, senaryo, görsel efektler, renkler, 1şıklar, teknoloji, yapay zekâ, şehir, sokaklar tamamen Cyberpunk ögeleri içermektedir. İç mekân tasarımı olarak Cyberpunk başlı başına bir akım olarak kullanılmamaktadır. Günümüz akımlarına benzer minimalist, fütürist ve modern tarzda olduğu görülmektedir. Soğuk, kasvetli, korkutucu ve olumsuz bir etki yaratılmak istendiğinden bazı mekânlarda bu etki, soğuk renkler, yetersiz düzeyde beyaz 1şıklar, loş mekânlar olarak tasvir edilmiştir. Blade Runner 2049 filminde iç mekânlar bu sebeple Cyberpunk türüne tam olarak uymamaktadır. Mobilyalarda ise tasarım çizgisi olarak modern ve minimalist mobilyalar görülmektedir. Teknoloji ile birleşim gerçekleştirmeyen, teknolojik nesnelerin mobilyalardan bağımsız olduğu görülmektedir.

"Ghost in the Shell" filminde teknoloji, iç mekân tasarımı ve mobilya tasarımında kısmen yer almaktadır. Mobilyalarda ve mekânlarda çoğunlukla hologram cihazları görülmektedir. Filmde hikâye, görsel efektler, teknoloji, yapay zekâ, şehir ve sokak hayatı Cyberpunk türüne örnek teşkil etmektedir. Genel olarak bu filmde de soğuk, kasvetli iç mekânlar yaratılmış ve teknolojinin insan hayatına olumsuz etkilerinden bahsedilmiştir. Yapılar modern ve fütüristik çizgide tasvir edilmiş, Japon kültürüne ait bazı imgelere yer verilmiştir. İç mekân ve mobilya tasarımları günümüz çizgisinde kurgulanmış ancak teknolojiye de yer verilmiş̧ir. Bu filmde de Cyberpunk iç mekân ve mobilya tasarımında başlı başına bir akım özelliği göstermemektedir. Cyberpunk türün kasvetli, soğuk, karanlık mekânlar yaratarak yansitılmıştır.

"Upgrade" filmi diğer iki film gibi hikâye, görsel efektler, yapay zekâ, teknoloji gibi konularda Cyberpunk türüne güzel bir örnektir. Modern mimarinin açıç̧a bir temsili söz konusudur. Beton ve doğanın uyumu, Frank Lloyd Wright etkisini aktarmaktadır. Filmde teknolojinin gelişmesi sonucunda doğa ile bir arada nasıl bir uyum içinde yaşayacağını ve aslında yaşamak zorunda olduğunu göstermektedir. İnsanların teknolojiye uyum sağlamak zorunda olduğunu ama aynı zamanda doğaya da muhtaç olduğunu anlatmaktadır. İç mekânlar diğer filmlerle ortak olarak kasvetli, karanlık ve soğuk olarak tasvir edilmektedir. Mobilyalar modern çizgide ve teknoloji ile birleşme sağlanmış ancak tam anlamıyla Cyberpunk ile bütünleşmemektedir. İncelenen üç filmde de teknoloji, Cyberpunk türüne uygun biçimde kullanılmıştır. Şehir ve sokak hayatı, insanların düşük seviyedeki yaşam kaliteleri, makineleşmenin ve transhümanizmin getirdiği olumsuzluklar ve Punk'ın barındırdığı unsurlara değinilmiş, yüksek yapılar, neon ışıklar göze çarpmaktadır. İç mekân ve mobilya tasarımları günümüz çizgisinde kullanılmıştır. Mobilya ve iç mekânlara eklenen hologram teknolojisi, dokunmatik teknolojik ekranlar tam anlamıyla Cyberpunk türünü yansıtmamaktadır.

Tablo 2. Filmlerin Özellikleri.

\begin{tabular}{|c|c|c|c|}
\hline Özellik & Blade Runner 2049 & Ghost in the Shell & Upgrade \\
\hline Biçim & Modern ve fütüristik yapılar & Modern ve fütüristik yapılar & Modern ve fütüristik yapılar \\
\hline Renk & $\begin{array}{l}\text { Soğuk renkler ve gri ve beyaz } \\
\text { tonları }\end{array}$ & $\begin{array}{l}\text { Soğuk renkler, gri ve beyaz } \\
\text { tonları }\end{array}$ & $\begin{array}{l}\text { Soğuk renkler, gri ve beyaz } \\
\text { tonları }\end{array}$ \\
\hline Işık & $\begin{array}{l}\text { Bölgesel aydınlatmalar, } \\
\text { çoğunlukla beyaz ışık, yer yer } \\
\text { sarı 1şık kullanımı }\end{array}$ & $\begin{array}{l}\text { Bölgesel aydınlatmalar, } \\
\text { çoğunlukla beyaz ışı, yer yer } \\
\text { sarı ışı kullanımı }\end{array}$ & $\begin{array}{l}\text { Bölgesel aydınlatmalar, beyaz } \\
\text { 1şık kullanımı }\end{array}$ \\
\hline Mobilya & $\begin{array}{l}\text { Minimalist ve modern çizgide, } \\
\text { teknoloji ile bütünleşmemiş } \\
\text { mobilyalar }\end{array}$ & $\begin{array}{lrr}\text { Minimalist, modern } & \text { çizginin } \\
\text { yanı sıra klasik } & \text { tarzda } \\
\text { mobilyalar da } & \text { mevcut. } \\
\text { Mobilya teknoloji } & \text { birleşimi } \\
\text { kısmen görülmekte } & \end{array}$ & $\begin{array}{l}\text { Minimalist ve modern çizgide, } \\
\text { teknoloji ile birleşim oldukça } \\
\text { göze çarpmakta }\end{array}$ \\
\hline
\end{tabular}




\begin{tabular}{|c|c|c|c|}
\hline Teknoloji & $\begin{array}{lcc}\text { Yüksek } & \text { teknolojiye } & \text { sahip } \\
\text { nesneler, } & \text { yapay } & \text { zekâ, } \\
\text { androidler } & & \end{array}$ & $\begin{array}{l}\text { Yüksek teknolojiye sahip } \\
\text { nesneler ve mobilyalar, yapay } \\
\text { zekâ, } \\
\text { transhümanizm androidler, }\end{array}$ & $\begin{array}{l}\text { Yüksek teknolojiye sahip } \\
\text { nesneler ve mobilyalar, } \\
\text { gelişmiş yapay zekâ, akıllı } \\
\text { robotlar, transhümanizm }\end{array}$ \\
\hline Nesne & $\begin{array}{l}\text { Hologram cihazlar1, akıllı } \\
\text { kontrol sistemleri, dronelar }\end{array}$ & $\begin{array}{l}\text { Hologram cihazları, büyük } \\
\text { robot makineler, gelişmiş } \\
\text { askeri güç }\end{array}$ & $\begin{array}{l}\text { Akıllı araçlar, gelişmiş askeri } \\
\text { teknoloji, }\end{array}$ \\
\hline Şehir & $\begin{array}{l}\text { Yozlaşmış, karışık ve kalabalık } \\
\text { şehirleşme, büyük hologram } \\
\text { reklamlar, mor, mavi neon } \\
\text { 1şıklar }\end{array}$ & $\begin{array}{l}\text { Fütüristik yapılar, kalabalık ve } \\
\text { beton yığını şehirleşme, } \\
\text { büyük hologram reklamlar, } \\
\text { mor, mavi neon ışılar }\end{array}$ & $\begin{array}{l}\text { Fütüristik yapılar, kalabalık } \\
\text { şehirler, ikonik yapılar, neon } \\
\text { 1şıklar }\end{array}$ \\
\hline
\end{tabular}
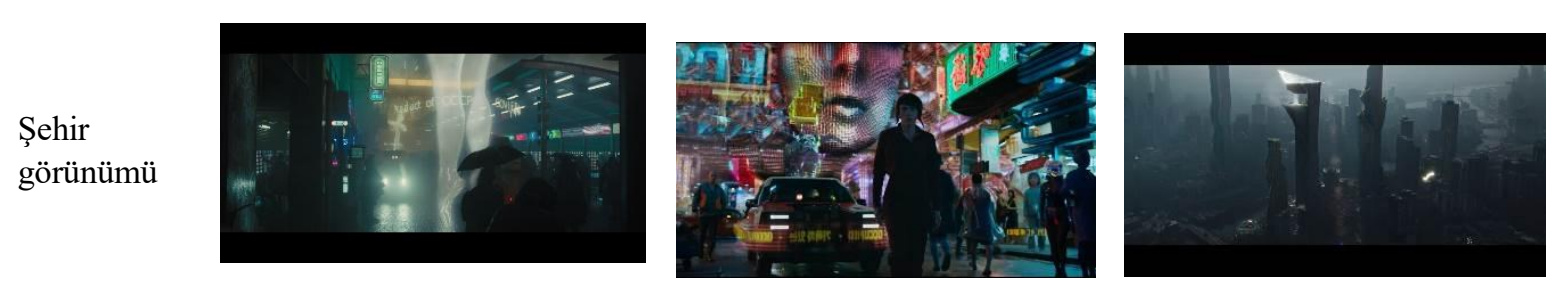

\section{Sonuç ve Tartışma}

Bahsedilen filmler ve günümüzdeki mekân örnekleri incelendiğinde Cyberpunk türünün kısıtlı kaldığı görülmektedir. Filmlerde edebi tür olarak Cyberpunk başarılı bir şekilde yansıtılmıştır. İncelenen üç filmde de ana karakterlerin kendi iç dünyaları ile yaşadıkları zıtlaşmalar, çarpışmalar anlatılmaktadır. Ancak teknolojinin hat safhaya ulaştığı bir gelecek tasvirinde mobilya ve iç mekân tasarımı konusuna gereken özveri sağlanmamıştır. Filmler teknolojik gelişmeleri ve buna bağlı olarak toplumların yaşadığı çöküşleri temel almıştır. Kaos, karmaşa, çöküş, istila gibi konuların üstünde durulurken, insanların yaşam kalitesinin düşmesinden bahsedilmiştir. Android robotlar, insan zekasına yetişmiş ve hatta geçmiş olan bir yapay zekâ, transhümanizmi barındıran filmler mobilya ve iç mekân tasarımı konularında yetersiz kalmaktadır. Cyberpunk türünü yansıtmak adına iç mekânlarda, soğuk, beyaz, gri renkler kullanılmış, bölgesel aydınlatmalara ve beyaz ışıklara yer verilmiştir. Öngörülen gelecek ile ilgili, mekân algısı soğuk, kasvetli olarak tasvir edilmesiyle yetinilmiştir. Filmler görsel efekt, hikâye ve içerdiği teknolojik gelişmeler ile Cyberpunk türünü yansıtırken, iç mekân ve mobilya tasarımı konusunda günümüz tasarımlarını kullanmıştır.

Örnek olarak verilen gerçek mekânlarda ise filmlerle benzer şekilde tasarımlar yer almaktadır. İç mekânlar günümüz çizgisinde tasarlanmıştır. Mobilyalar ise minimalist ve modern çizgide, günümüz anlayışının ötesine geçebilmiş değildir. Azami sayıda neon 1şık kullanımı göze çarpmaktadır.

Filmler ve gerçek mekânların ortak özellikleri konusunda göstergebilim 1şı̆̆ında bir değerlendirme olarak; Cyberpunk türünün yarattığı istila, kaos, çöküş gibi kavramlar, iç mekânlarda yalnızca renkler ve 1şıklar ile yansıtılmaya çalışılmıştır. Bu bağlamda hala teknoloji ile tam olarak bütünleşememiş olan Cyberpunk türü, iç mekân ve mobilya tasarımı konusunda da teknoloji ile bütünleşememiştir. Cyberpunk'ın 'Yüksek teknoloji, düşük yaşam kalitesi'" mottosu ile, teknolojinin bu yükselişi iç mekân ve mobilya tasarımında da yer almalı ve geleceğin bu karanlık öngörüleri üzerinden yeni bir tasarım üslubu ortaya konmalıdır. 
Bilgilendirme / Acknowledgement:

1- Araştırmacıların katkı oranı eşittir.

2- Makalenin yazarları arasında çıkar çatışması bulunmamaktadır.

3- Makalemizde etik kurulu izni ve/veya yasal/özel izin alınmasını gerektiren bir durum yoktur.

4- Bu makalede araştırma ve yayın etiğine uyulmuştur.

\section{KAYNAKÇA}

Altan, İ. (1993). Mimarlikta mekân kavramı. Psikoloji Çalışmaları, 19, 75-88

Ayyıldız, S. ve Müştak, S. (2016). Sinema-mimarlık arakesitinde cyberpunk (siberpunk) ve "Ada" filmi üzerinden eleştirel bir yaklaşım. Mimarlık ve Yaşam Dergisi, 1(1), 127 142

Bağcıvan, H. ve Durmuş, M. (2019). Blade runner filminin bilimkurgu tasarım dili açısından görsel analizi. Sosyal Bilimler Dergisi, 35, 302-322

Başaran B. (2007). Fütürizm'den siber punk'a: yirminci yüzyıl sanatında teknolojinin değişen yansıması. Yayımlanmamış yüksek lisans tezi, Marmara Üniversitesi, İstanbul.

Beşışık, G. (2013). Sinema ve mimarlıkta mekân kurgusu ve kavrayışı. Yayımlanmamış yüksek lisans tezi, Dokuz Eylül Üniversitesi, İzmir.

Bezci, İ. ve Dündar Türkkan, V. (2017). Teknoloji ve mobilya ilişkisinin bilim kurgu filmleri üzerinden incelenmesi. Ileri Teknoloji Bilimleri Dergisi, 6(3), 351-359

Cavallaro, D. (2000). Cyberpunk and cyberculture. Londra: The Athlone

Ersoy, E. (2010). Mimarlık ve sinema etkileşimi bağlamında mekânsal imge kullanımıyla durağan mekânın dinamik mekâna dönüşümü. Yayımlanmamış yüksek lisans tezi, İstanbul Teknik Üniversitesi, İstanbul.

Ersümer, O. (2013). Bilimkurgu sinemasında cyberpunk. İstanbul: Altıkırkbeş.

Inside the world's first cyber maid cafe: Akiba Zettai Ryoiki A.D. 2045. (2020). 18 Mayıs 2020 tarihinde https://www.tokyoweekender.com/2019/06/inside-the-worlds-first-cybermaid-cafe-akiba-zettai-ryoiki-a-d-2045/ adresinden erişildi.

Kutucu, S. (2003). Sinemada marjinallik ve mekân, Ege Mimarlık, 45, 26-28.

Özturan, Ö. (2010). Teknolojik gelişmelerin iç mekân biçimlenişine etkisi. ITÜY, Tasarımda Genç Bakışlar Ulusal Sempozyumu, 125-135.

Rasmussen, S. E. (2010). Yaşayan mimari. İstanbul: Remzi Kitabevi.

Sevin B. (2018). Edebiyat, sinema, mekân arasındaki geçişgenlik üzerine bir araştırma: steampunk ve siberpunk'ın farklı tasarım sahalarındaki izdüşümleri. Yayımlanmamış yüksek lisans tezi, Mimar Sinan Güzel Sanatlar Üniversitesi, İstanbul.

Uğur, S. (2018). Transhumanizm ve öğrenmedeki değişim. Açıköğretim Uygulamaları ve Araştırmaları Dergisi, 4(3), 58-74.

Usta, G. (2020). Mekân ve yer kavramlarının anlamsal açıdan irdelenmesi. TOJDAC Dergisi, 10(1), 25-30. 


\section{Görsel Kaynakça}

Resim 24. 16 Mayis 2020 tarihinde https://www.behance.net/gallery/67329831/Cyberpunk2077-at-E3?tracking_source=search\%7Cprojekt\%20na\%20pude\%C5\%82ko adresinden erişildi

Resim 25. 16 Mayis 2020 tarihinde https://www.behance.net/gallery/67329831/Cyberpunk2077-at-E3?tracking_source=search\%7Cprojekt\%20na\%20pude\%C5\%82ko adresinden erişildi.

Resim 26. 16 Mayis 2020 tarihinde https://www.behance.net/gallery/67329831/Cyberpunk2077-at-E3?tracking_source=search\%7Cprojekt\%20na\%20pude\%C5\%82ko adresinden erişildi.

Resim 27. 18 May1s 2020 tarihinde https://www.tokyoweekender.com/2019/06/inside-theworlds-first-cyber-maid-cafe-akiba-zettai-ryoiki-a-d-2045/ adresinden erişildi.

Resim 28. 20 Mayıs 2020 tarihinde https://tr.wikipedia.org/wiki/Nakagin_Kapsül_Kulesi ve https://www.archdaily.com/110745/ad-classics-nakagin-capsule-tower-kishokurokawa adresinden erişildi. 